\title{
Comparison of Vaisala radiosondes RS41 and RS92 at the ARM Southern Great Plains site
}

\author{
Michael P. Jensen ${ }^{1}$, Donna J. Holdridge ${ }^{2}$, Petteri Survo ${ }^{3}$, Raisa Lehtinen ${ }^{3}$, Shannon Baxter ${ }^{1,4}$, Tami Toto ${ }^{1}$, and \\ Karen L. Johnson ${ }^{1}$ \\ ${ }^{1}$ Brookhaven National Laboratory, Upton, NY, USA \\ ${ }^{2}$ Argonne National Laboratory, Argonne, IL, USA \\ ${ }^{3}$ Vaisala Oyj, Helsinki, Finland \\ ${ }^{4}$ State University of New York, Geneseo, NY, USA
}

Correspondence to: Michael P. Jensen (mjensen@bnl.gov)

Received: 31 August 2015 - Published in Atmos. Meas. Tech. Discuss.: 2 November 2015

Revised: 3 June 2016 - Accepted: 27 June 2016 - Published: 20 July 2016

\begin{abstract}
In the fall of 2013, the Vaisala RS41 (fourth generation) radiosonde was introduced as a replacement for the RS92-SGP radiosonde with improvements in measurement accuracy of profiles of atmospheric temperature, humidity, and pressure. In order to help characterize these improvements, an intercomparison campaign was undertaken at the US Department of Energy's Atmospheric Radiation Measurement (ARM) Climate Research Facility site in northcentral Oklahoma, USA. During 3-8 June 2014, a total of 20 twin-radiosonde flights were performed in a variety of atmospheric conditions representing typical midlatitude continental summertime conditions. The results show that for most of the observed conditions the RS92 and RS41 measurements agree much better than the manufacturer-specified combined uncertainties with notable exceptions when exiting liquid cloud layers where the "wet-bulbing" effect appears to be mitigated for several cases in the RS41 observations. The RS41 measurements of temperature and humidity, with applied correction algorithms, also appear to show less sensitivity to solar heating. These results suggest that the RS41 does provide important improvements, particularly in cloudy conditions. For many science applications - such as atmospheric process studies, retrieval development, and weather forecasting and climate modeling - the differences between the RS92 and RS41 measurements should have little impact. However, for long-term trend analysis and other climate applications, additional characterization of the RS41 measurements and their relation to the long-term observational records will be required.
\end{abstract}

\section{Introduction}

Since the 1930s measurements of tropospheric temperature, pressure, water vapor, and winds have been made by radiosondes attached to balloons. These measurements provide critical input to weather forecasting and climate models, quantification of atmospheric thermodynamic stability, input to remote-sensing retrievals, and important constraints for atmospheric process studies. The long history of radiosonde observations includes many changes in instrumentation, practices, processing, and other issues (e.g., Elliot and Gaffen, 1991; Gaffen, 1993; Elliot et al., 1998; Wang et al., 2003; Haimberger, 2007; Vömel et al., 2007; Haimberger et al., 2008; Rowe et al., 2008; Sherwood et al., 2008; McCarthy et al., 2009; Milosevich et al., 2004, 2009; Seidel et al., 2009; Dai et al.,2010; Immler et al., 2010; Thorne et al., 2011; Zhao et al., 2012; Moradi et al., 2013; Wang et al., 2013; Dirksen et al., 2014; Yu et al., 2015; Bodeker et al., 2016).

The US Department of Energy's Atmospheric Radiation Measurement (ARM) Climate Research Facility (Mather and Voyles, 2013; Ackerman and Stokes, 2003; Stokes and Schwartz, 1994; http://www.arm.gov) operates three fixed field sites (Southern Great Plains (SGP), Oklahoma, USA; North Slope, Alaska, USA; and Eastern North Atlantic, Azores, Portugal) and three mobile field sites to study the effects of aerosols, precipitation, surface fluxes, and clouds on global climate. One important component of the measurements at each of these sites is the routine launching of radiosondes two-four times per day, resulting in more than 
Table 1. Summary of key physical characteristics of the RS41 and RS92 radiosonde models (based on Table 1 from Jauhiainen et al., 2014).

\begin{tabular}{lll}
\hline Radiosonde characteristic & RS41 & RS92 \\
Weight & $109 \mathrm{~g}$ & $280 \mathrm{~g}$ \\
Dimensions & $272 \times 63 \times 46 \mathrm{~mm}$ & $220 \times 80 \times 75 \mathrm{~mm}$ \\
Battery type & Lithium, nominal 3 V (integrated) & Alkaline, nominal 9 V (separate battery) \\
Battery capacity & $>240 \mathrm{~min}$ & $135 \mathrm{~min}$ \\
Transmitter power & Min. $60 \mathrm{~mW}$ & $60 \mathrm{~mW}$ \\
Telemetry range (with RB31 antenna) & $350 \mathrm{~km}$ & $350 \mathrm{~km}$ \\
Measurement cycle & $1 \mathrm{~s}$ & $1 \mathrm{~s}$ \\
\hline
\end{tabular}

5000 launches per year. During this period the ARM program has used Vaisala radiosondes as part of regular operations and intensive operational periods (e.g., Ghan et al., 2000; Xu et al., 2002; Xie et al., 2005; Miller et al., 2007; Jensen et al., 2015, 2016). The RS92 radiosonde is the current standard at all of the ARM sites and has been in use since 2005. The observations from these soundings have been used for many scientific applications, including the derivation of large-scale forcing datasets for modeling studies (e.g., Zhang and Lin, 1997; Zhang et al., 2001; Xie et al., 2010, 2015), constraints on cloud remote-sensing retrievals (e.g., Zhao et al., 2012; Huang et al., 2012; Dunn et al., 2011), and quantification of atmospheric thermodynamic structure (e.g., Sawyer and Li 2013; McFarlane et al., 2013).

The Vaisala RS41 (fourth generation) radiosonde was developed to replace the RS92 and was introduced in the fall of 2013 aimed at delivering improvements in measurement accuracy of profiles of atmospheric temperature, humidity, and pressure. In order to characterize the improvements and differences of the RS41 radiosonde compared to the RS92, a number of intercomparison campaigns have been undertaken in varying environments, including midlatitude test campaigns at Libus, Prague, Czech Republic (Motl, 2014), in August 2013 and by the UK Met Office at Camborne, UK (Edwards et al., 2014), in November 2013. Higher-latitude testing has been done in Finland (Vantaa and Sodankylä), and tropical conditions were sampled in Penang, Malaysia (Jauhiainen et al., 2014). This manuscript will describe the results of an intercomparison study of the new RS41 and RS92 Vaisala radiosondes at north-central Oklahoma, USA, in June 2014. This new study distinguishes itself through a focus on a midlatitude summertime convective environment and the ability to leverage independent observations of clouds and atmospheric state from the ARM Climate Research Facility. Section 2 describes the differences between the two radiosonde types. Section 3 describes the experimental design, and Sect. 4 describes the results of the intercomparison. Section 5 summarizes and discusses the implications of the results.
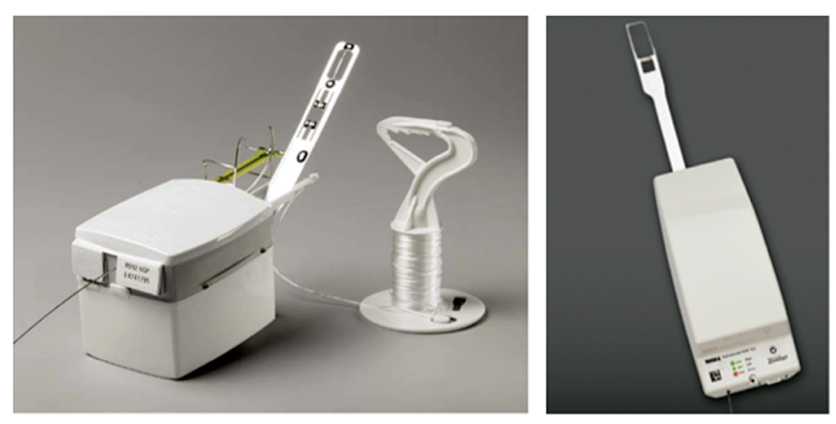

Figure 1. Picture of two radiosonde types used in this study: RS92 (left) and RS41 (right).

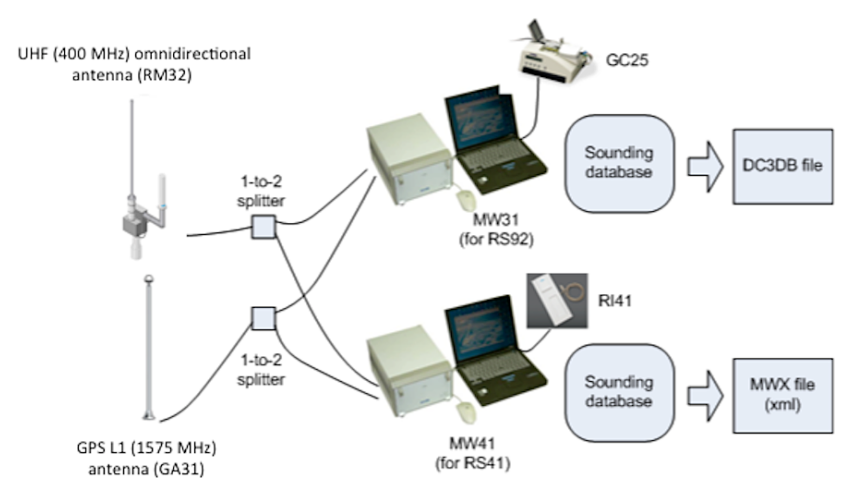

Figure 2. Experimental system setup: antennae, sounding system, and ground check system.

\section{Differences between the RS92 and RS41 radiosondes}

Figure 1 shows a picture of the two radiosonde types, and Fig. 2 the complete system setup used in the trial. When comparing the radiosonde RS41 and Vaisala DigiCORA ${ }^{\circledR}$ Sounding System MW41 with the older-generation RS92 and Vaisala DigiCORA ${ }^{\circledR}$ Sounding System MW31, the new setup includes improved sensor technologies and easier operational sounding preparations, aimed at higher accuracy and better data consistency in operational radiosoundings. Table 1 summarizes some of the key physical characteristics of the two radiosonde models. The RS41 is lighter and thinner than the RS92 and includes a smaller internal lithium battery compared to a separate alkaline battery for the RS92, 
Table 2. Radiosonde temperature sensor manufacturer specifications (based on Table 3 from Jauhiainen et al., 2014).

\begin{tabular}{|c|c|c|}
\hline $\begin{array}{l}\text { Radiosonde } \\
\text { characteristics }\end{array}$ & RS41 & RS92 \\
\hline \multicolumn{3}{|l|}{ Temperature } \\
\hline Sensor type & Platinum resistor & Capacitive wire \\
\hline Range & +60 to $-90^{\circ} \mathrm{C}$ & +60 to $-90^{\circ} \mathrm{C}$ \\
\hline Resolution & $0.01^{\circ} \mathrm{C}$ & $0.01^{\circ} \mathrm{C}$ \\
\hline Response time $^{1}$ & $0.5 \mathrm{~s}$ & $<0.4 \mathrm{~s}$ \\
\hline Combined uncertainty & $0.3^{\circ} \mathrm{C}<16 \mathrm{~km}$ & $0.5^{\circ} \mathrm{C}<16 \mathrm{~km}$ \\
\hline in sounding ${ }^{2}$ & $0.4^{\circ} \mathrm{C}>16 \mathrm{~km}$ & $0.5^{\circ} \mathrm{C}>16 \mathrm{~km}$ \\
\hline Reproducibility & $0.15^{\circ} \mathrm{C}>100 \mathrm{hPa}$ & $0.2^{\circ} \mathrm{C}>100 \mathrm{hPa}$ \\
\hline in sounding ${ }^{3}$ & $0.3^{\circ} \mathrm{C}<100 \mathrm{hPa}$ & $0.5^{\circ} \mathrm{C}<100 \mathrm{hPa}$ \\
\hline
\end{tabular}

${ }^{1} 63.2 \%$ relative humidity, $6 \mathrm{~m} \mathrm{~s}^{-1}$ flow, $1000 \mathrm{hPa}^{2} 2$-sigma $(k=2)$ confidence level $(95.5 \%)$ cumulative measurement uncertainty. ${ }^{3}$ Standard deviation of differences in twin soundings, ascent rate above $3 \mathrm{~m} \mathrm{~s}^{-1}$.

which must be attached during launch preparation. The sensor characteristics for the two radiosondes are compared in Tables 2-4. The RS41 uses a resistive platinum temperature sensor compared to a capacitive wire sensor for the RS92. The RS41 temperature sensor has improved resolution and smaller combined uncertainty but slightly slower response time compared to the RS92 (Table 2; Vaisala, 2014). For humidity observations the RS41 uses a thin-film capacitor with an integrated temperature sensor and heating functionality, while the RS92 uses a thin-film capacitor with a heated twin sensor. In both radiosonde models heating is used as a means for deicing the humidity sensor when a radiosonde traverses through cloud layers with freezing conditions. In the case of the RS41, a controlled heating is applied for the purpose, whereas in the RS92 the two sensors are pulseheated sequentially. In general, the RS41 humidity sensor has improved resolution and response time, and smaller combined uncertainty compared with the RS92 (Table 3; Vaisala, 2014). The RS41 model used in this trial, RS41-SG, makes use of GPS observation of vertical displacement along with the temperature and humidity measurements to derive the atmospheric pressure, while the RS92 model, RS92-SGPD, uses a direct measurement of pressure with a silicon capacitive sensor. Note that there is also a model RS41-SGP with a pressure sensor, similar to the RS92-SGPD, and, with both models, it is possible to configure the sounding system to utilize either sensor or GPS-based pressure for the sounding profile. The GPS-derived pressure values for the RS41 have improved resolution and smaller combined uncertainty at pressures lower than $100 \mathrm{hPa}$ compared to the RS92 sensor measured pressure (Table 4; Vaisala, 2014). Both the RS41 and RS92 use GPS to derive wind speed and direction with similar measurement performance (velocity uncertainty $=0.15 \mathrm{~m} \mathrm{~s}^{-1}$; direction uncertainty $=2^{\circ}$ for wind speed greater than $3 \mathrm{~m} \mathrm{~s}^{-1}$; Vaisala, 2014).
In general, the two radiosonde models apply similar types of corrections for the edited pressure, temperature, and humidity sounding data. However, there are a couple of significant differences between the corrections worth mentioning. In the ground check phase, no ground check correction is applied for the RS41 temperature measurement. A functionality check and a comparison of readings with the temperature sensor of the humidity sensor chip are performed instead. Another major difference is related to the approach on how the humidity measurements take into account the effect of solar radiation. In the case of the RS92, the increment in humidity sensor temperature is estimated taking into account the solar radiation intensity and the related physics, and the humidity measurement result is corrected accordingly. In contrast, the RS41 humidity sensor incorporates an on-chip temperature sensor, and, thus, the temperature of the humidity sensor is continuously measured and taken into account in the relative humidity calculations. In other words, no separate solar radiation correction is needed nor applied for the RS41 humidity measurement.

A notable difference in the two sounding systems is that the launch procedure for the RS41 radiosonde is much simpler than that for the RS92. In particular, the RS41 is powered with integrated batteries, removing the need to open the body and connect the battery as in the RS92. The RS41 also has status LED indicators that indicate launch readiness as the radiosonde goes through the ground check procedure and selfdiagnostics prior to launch. Also, when the RS41 is prepared with the ground check device RI41, it implements a zerohumidity check procedure in ambient air, while the GC25 uses a desiccant-based dry condition as a reference. For the RS41, the dry reference condition of the zero-humidity check procedure is generated by heating the sensor using the integrated heating element on the sensor chip. The procedure uses the fact that, for a given water vapor content, relative humidity decreases towards zero as the temperature rises. This change removes the need for maintenance of the desiccant, a source of operator error. An uncertainty study of the RS41 relative humidity measurements after ground preparation shows an uncertainty $(k=2)$ of $0.5-2 \% \mathrm{RH}$ at a temperature of $20^{\circ} \mathrm{C}$ and $\mathrm{RH}$ ranging from 0 to $100 \%$ (Vaisala, 2013), and laboratory test results support the stated uncertainties (Vaisala, 2015).

\section{Experimental design}

In order to directly compare observations from the RS41 and RS92 radiosondes, a twin-sounding method, which is a simplified version of the World Meteorological Organization radiosonde intercomparison test method (Nash et al., 2010), is used. For the experiment, two separate DigiCORA sounding systems were used: an MW31 - including an SPS311 sounding processing subsystem, a sounding workstation (laptop) running DigiCORA software v3.66, and a GC25 ground 
Table 3. Radiosonde humidity sensor manufacturer specifications (based on Table 4 from Jauhiainen et al., 2014).

\begin{tabular}{lll}
\hline Radiosonde characteristics & RS41 & RS92 \\
\hline Humidity & & \\
\hline Sensor type & $\begin{array}{l}\text { Thin-film capacitor, integrated T sensor } \\
\text { and heating functionality }\end{array}$ & Thin-film capacitor, \\
& $0-100 \%$ & $0-100 \%$ \\
Range & $0.1 \%$ & $0.1 \%$ \\
Resolution & $<0.3 \mathrm{~s}$ & $<0.5 \mathrm{~s}$ \\
Response time warm ${ }^{1}$ & $<10 \mathrm{~s}$ & $<20 \mathrm{~s}$ \\
Response time cold & & $5 \% \mathrm{RH}$ \\
Combined uncertainty in sounding $^{3}$ & $4 \% \mathrm{RH}$ & $2 \% \mathrm{RH}$ \\
Reproducibility in sounding $^{4}$ & $2 \% \mathrm{RH}$ & \\
\hline
\end{tabular}

${ }^{1} 63.2 \%$ relative humidity, $6 \mathrm{~m} \mathrm{~s}^{-1}$ flow, $1000 \mathrm{hPa},+20^{\circ} \mathrm{C} .{ }^{2} 63.2 \%$ relative humidity, $6 \mathrm{~m} \mathrm{~s}^{-1}$ flow, $1000 \mathrm{hPa},-40{ }^{\circ} \mathrm{C} .{ }^{3}$ 2-sigma $(k=2)$ confidence level $(95.5 \%)$ cumulative measurement uncertainty. ${ }^{4}$ Standard deviation on differences in two soundings, ascent rate above $3 \mathrm{~m} \mathrm{~s}^{-1}$.

Table 4. Radiosonde pressure sensor measurement specifications (based on Table 5 from Jauhiainen et al., 2014).

\begin{tabular}{lll}
\hline $\begin{array}{l}\text { Radiosonde } \\
\text { characteristics }\end{array}$ & RS41 & RS92 \\
\hline Pressure & GPS derived & $\begin{array}{l}\text { Silicon, } \\
\text { Capacitive } \\
\text { sensor }\end{array}$ \\
Measurement & & $1080-3 \mathrm{hPa}$ \\
principle & Surface to $3 \mathrm{hPa}$ & $0.01 \mathrm{hPa}$ \\
Range & $0.01 \mathrm{hPa}$ & $1.0>100 \mathrm{hPa}$ \\
Resolution & $1.0>100 \mathrm{hPa}$ & $0.6<100 \mathrm{hPa}$ \\
Combined uncertainty & $0.3<100 \mathrm{hPa}$ & $0.6<10 \mathrm{hPa}$ \\
in sounding ${ }^{1}$ & $0.04<10 \mathrm{hPa}$ & $0.5>100 \mathrm{hPa}$ \\
& $0.5>100 \mathrm{hPa}$ & $0.3<100 \mathrm{hPa}$ \\
Reproducibility & $0.2<100 \mathrm{hPa}$ & $0.3<10 \mathrm{hPa}$ \\
in sounding ${ }^{2}$ & $0.04<10 \mathrm{hPa}$ & \\
\end{tabular}

1 2-sigma $(k=2)$ confidence level $(95.5 \%)$ cumulative measurement uncertainty. ${ }^{2}$ Standard deviation on differences in two soundings, ascent rate above $3 \mathrm{~m} \mathrm{~s}^{-1}$.

check device - and an MW41, including an SPS311 sounding processing subsystem, a sounding workstation (laptop) running MW41 sounding software v2.1.0, and a Vaisala RI41 ground check device (Fig. 2). All correction algorithms were enabled in the sounding systems, and, specifically, the solar radiation corrections for the temperature and humidity measurements, updated since version 3.64, were applied in MW31 calculations. The systems were set up to share one set of ultra-high-frequency antenna (RM32) and omnidirectional GPS antenna (GA31) as shown in Fig. 2.

The twin-sounding method required special equipment and rigging. During the intercomparison study both types of radiosonde (RS41 and RS92) were flown together on a single $600 \mathrm{~g}$ Totex balloon. A heavy-duty Graw UW130 ozonesonde unwinder was used with $30 \mathrm{~m}$ of unwinder string. This was attached to a $1.5 \mathrm{~m}$ wooden rod from which

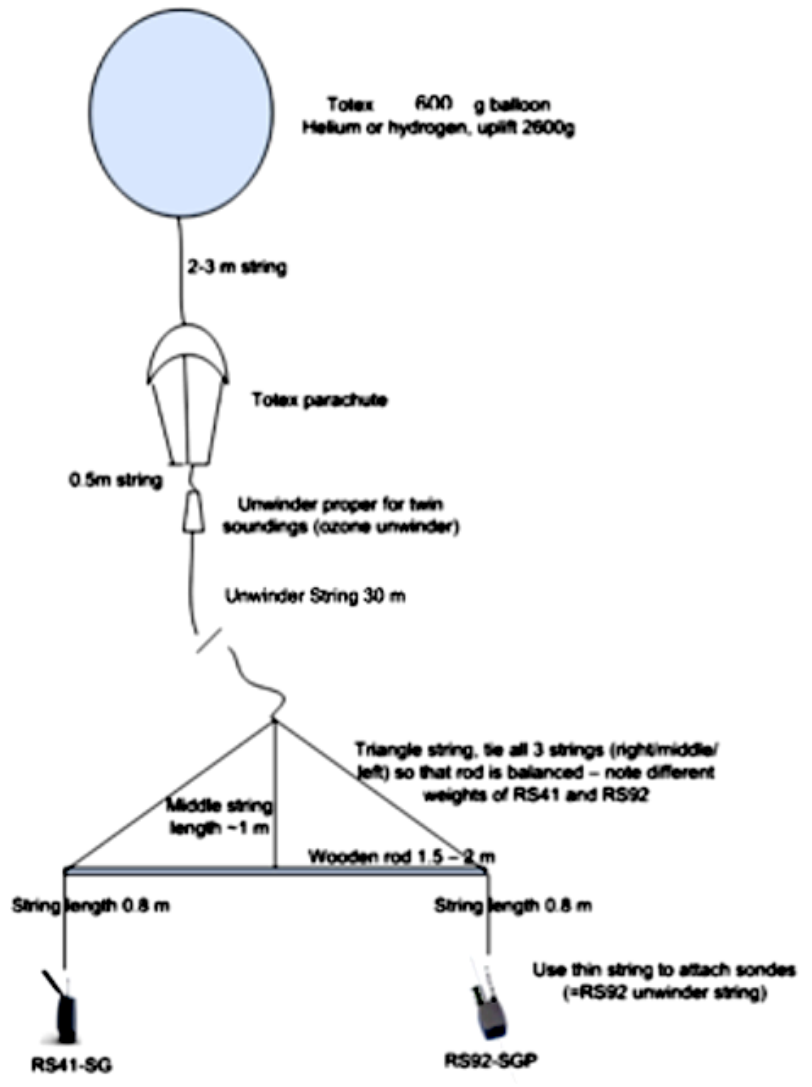

Figure 3. Experimental setup: balloon, parachute, unwinder, rigging, and radiosondes.

the radiosondes were hung at equal distance below the balloon. A parachute was also included to slow the descent of the rigging after the balloon burst. Figure 3 shows a schematic of the equipment used for the twin-radiosonde flights. It should be noted that measurement conditions of a radiosonde are not exactly the same in twin sounding as in single radiosonde soundings. In the twin sounding - due to 


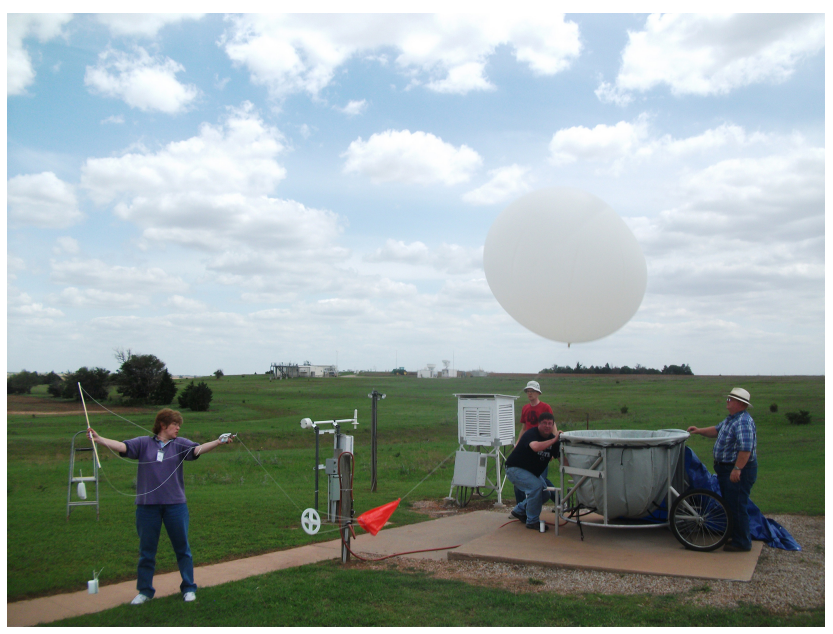

Figure 4. Radiosonde launch at the ARM Southern Great Plains site.

Table 5. Radiosonde launch characteristics.

\begin{tabular}{llrr}
\hline $\begin{array}{l}\text { Launch } \\
\text { no. }\end{array}$ & $\begin{array}{l}\text { Launch time } \\
(\mathrm{LT}=\mathrm{GMT}-5)\end{array}$ & $\begin{array}{r}\text { Maximum } \\
\text { height } \\
(\mathrm{km})\end{array}$ & $\begin{array}{r}\text { Mean ascent } \\
\text { rate }\left(\mathrm{m} \mathrm{s}^{-1}\right) \\
\text { to } 200 \mathrm{hPa}\end{array}$ \\
\hline 1 & 3 June 12:55 & 31.096 & 4.8 \\
2 & 3 June 15:43 & 29.881 & 5.6 \\
3 & 3 June 17:46 & 28.660 & 4.7 \\
4 & 3 June 22:07 (Night) & 29.378 & 6.4 \\
5 & 3 June 23:59 (Night) & 30.334 & 6.0 \\
6 & 4 June 12:57 & 29.487 & 6.2 \\
7 & 4 June 14:50 & 29.954 & 6.0 \\
8 & 4 June 17:13 & 29.808 & 6.2 \\
9 & 5 June 09:50 & 28.088 & 6.1 \\
10 & 5 June 11:34 & 28.119 & 5.9 \\
11 & 5 June 14:57 & 28.729 & 5.5 \\
12 & 5 June 21:59 (Night) & 29.821 & 6.7 \\
13 & 5 June 23:39 (Night) & 29.800 & 5.6 \\
14 & 6 June 15:26 & 28.078 & 6.3 \\
15 & 6 June 19:16 & 28.799 & 6.3 \\
16 & 7 June 09:35 & 28.725 & 6.0 \\
17 & 7 June 11:16 & 28.449 & 6.0 \\
18 & 7 June 20:09 & 29.697 & 5.1 \\
19 & 7 June 22:08 (Night) & 29.868 & 6.0 \\
20 & 7 June 23:55 (Night) & 25.957 & 6.1 \\
\hline
\end{tabular}

higher inertia and drag of the payload, and thus more stable flight - the sensors generally have slightly less ventilation. A larger payload may also magnify the effects of some error sources, for example, temperature sensor orientation error caused by solar radiation. Figure 4 shows a photograph of the launch of a twin-sounding rig from the ARM SGP site.

From 3 to 8 June 2014, a series of weather balloon flights were performed at the ARM SGP Central Facility $\left(36.695^{\circ}\right.$ latitude, $-97.485^{\circ}$ longitude) with the goal of evaluating the relative performance of the RS92-MW31 and RS41-MW41
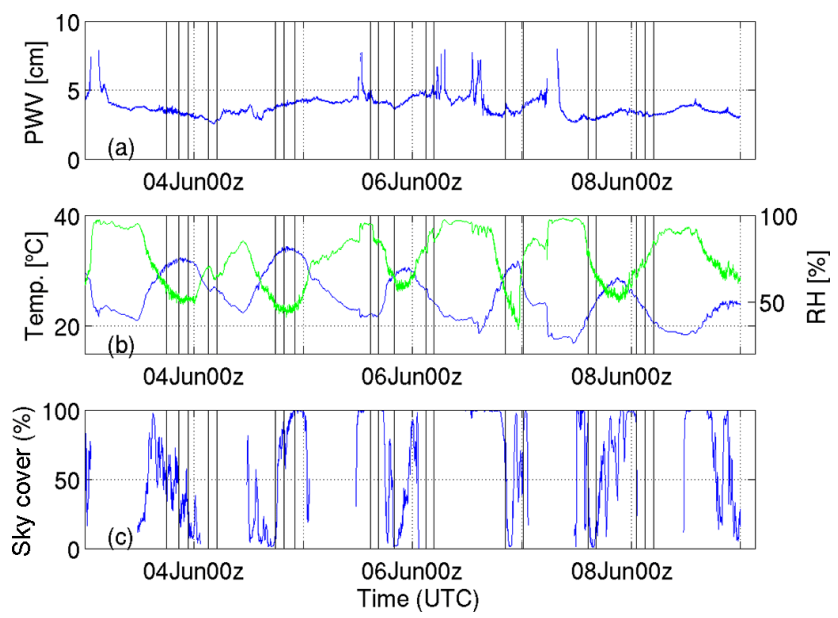

Figure 5. Time series of surface-based meteorological observations: (a) precipitable water vapor (PWV) retrieved from a twochannel microwave radiometer, (b) surface temperature (blue) and relative humidity (green), and (c) hemispheric sky cover as observed by a total sky imager (TSI). Vertical black lines represent the times of radiosonde launches.

radiosonde-system setups. The June time period at SGP represented a summertime midlatitude convective environment during which complementary in situ and remote-sensing observations at the SGP site were used to further quantify the environment during the intercomparison. Over the course of 5 days a total of 20 balloon flights were completed with efforts to sample the entire diurnal cycle and a variety of cloud conditions (avoiding heavy precipitation, which could result in launch failures).

Table 5 summarizes the basic characteristics of the 20 radiosonde flights at the ARM SGP site. Efforts were made to sample the daytime diurnal cycle and also to include several nighttime flights where heating by solar radiation would not be an issue. All 20 flights were considered successful, with sampling through the atmosphere to a height of at least $28 \mathrm{~km}$ for 19 of the 20 soundings (The final flight terminated at a height just below $26 \mathrm{~km}$ ). Figure 5 shows the time series of (a) precipitable water vapor as retrieved from a twochannel microwave radiometer (MWR; Turner et al., 2007), (b) surface dry-bulb temperature and relative humidity, and (c) hemispheric sky cover as observed from a total sky imager (Long et al., 2001). Table 6 shows the numerical values of these quantities at the launch time for each sounding. A variety of conditions were sampled, including six nighttime soundings, surface temperatures ranging from 20.4 to $33.1{ }^{\circ} \mathrm{C}$, surface relative humidity ranging from 46 to $96 \%$, precipitable water vapor ranging from 2.55 to $4.77 \mathrm{~cm}$, and hemispheric sky cover ranging from 2 to $100 \%$. Figure 6 shows hourly profiles of cloud frequency of occurrence derived from the Active Remote Sensing of CLouds (ARSCL) value-added data product (Clothiaux et al., 2000; Kollias et al., 2007), which uses a combination of Ka-band ARM 
Table 6. Surface observations of meteorological state for each launch. Pressure, temperature, relative humidity, wind speed, and wind direction observations are from THWAPS (temperature, humidity, wind, and pressure sensor; www.arm.gov/instruments/thwaps). Sky cover is from the total sky imager, and precipitable water vapor is from the microwave radiometer.

\begin{tabular}{lrrrrrrr}
\hline Flight no. & $\begin{array}{r}\text { Pressure } \\
(\mathrm{hPa})\end{array}$ & $\begin{array}{r}\text { Temperature } \\
\left({ }^{\circ} \mathrm{C}\right)\end{array}$ & $\begin{array}{r}\text { RH } \\
(\%)\end{array}$ & $\begin{array}{r}\text { Wind speed } \\
\left(\mathrm{m} \mathrm{s}^{-1}\right)\end{array}$ & $\begin{array}{r}\text { Wind dir. } \\
\left({ }^{\circ}\right)\end{array}$ & $\begin{array}{r}\text { Sky cover } \\
(\%)\end{array}$ & $\begin{array}{r}\text { Precipitable water } \\
\text { vapor }(\mathrm{cm})\end{array}$ \\
\hline 1 & 975.95 & 31.0 & 60 & 9.0 & 173 & 54.28 & 3.57 \\
2 & 973.83 & 31.8 & 51 & 8.5 & 166 & 22.54 & 3.32 \\
3 & 971.74 & 31.1 & 51 & 10.5 & 173 & 10.64 & 3.24 \\
4 & 969.07 & 26.0 & 70 & 4.6 & 174 & - & 2.76 \\
5 & 970.07 & 25.9 & 65 & 7.2 & 191 & - & 2.85 \\
6 & 970.12 & 32.4 & 46 & 4.1 & 223 & 23.74 & 3.84 \\
7 & 969.75 & 33.1 & 46 & 4.0 & 205 & 71.99 & 3.90 \\
8 & 969.10 & 32.9 & 49 & 4.0 & 180 & 99.55 & 4.17 \\
9 & 968.44 & 22.0 & 96 & 4.0 & 74 & 99.78 & 4.44 \\
10 & 968.31 & 21.7 & 86 & 5.5 & 76 & 99.65 & 4.07 \\
11 & 970.96 & 28.6 & 63 & 3.8 & 127 & 1.67 & 3.68 \\
12 & 973.60 & 26.3 & 81 & 2.8 & 59 & - & 4.56 \\
13 & 973.40 & 23.9 & 88 & 9.5 & 79 & - & 3.77 \\
14 & 975.02 & 28.9 & 56 & 1.8 & 295 & 35.26 & 3.74 \\
15 & 972.55 & 26.6 & 76 & 5.0 & 95 & 91.53 & 2.94 \\
16 & 975.50 & 20.9 & 78 & 7.4 & 325 & 17.69 & 2.97 \\
17 & 975.58 & 24.0 & 65 & 5.0 & 320 & 16.34 & 3.37 \\
18 & 976.12 & 25.1 & 64 & 1.6 & 10 & 47.64 & 3.31 \\
19 & 976.38 & 22.6 & 73 & 3.8 & 58 & - & 3.23 \\
20 & 977.46 & 20.4 & 84 & 1.3 & 62 & & - \\
\hline
\end{tabular}

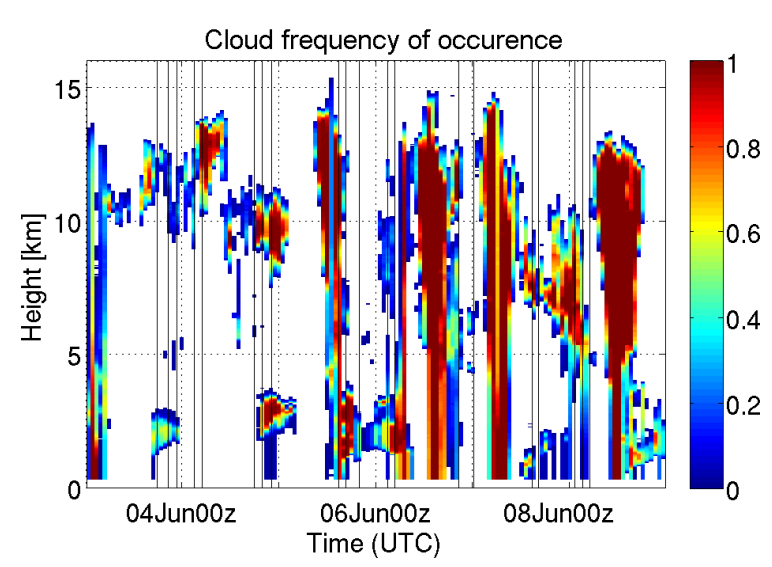

Figure 6. Cloud frequency of occurrence as a function of time and height (above mean sea level) based on the Active Remote Sensing of CLouds (ARSCL) product. Occurrence statistics are determined over a $1 \mathrm{~h}$ time window and a $30 \mathrm{~m}$ height window. Vertical black lines represent the times of radiosonde launches.

zenith-pointing radar (KAZR), micropulse lidar (MPL), and ceilometer observations to produce a best estimate of cloud occurrence. Launches occurred over a variety of cloud conditions including single- and multi-layer low- and high-level clouds.

\section{Results}

Figure 7 shows a typical example - from 3 June 2014 at 17:46 LT, balloon flight no. 3 - of the observations collected during a weather balloon flight. This profile shows a temperature inversion with a base near $775 \mathrm{hPa}$ and a very dry troposphere above. The RS41 and RS92 radiosondes showed very similar results for all measurement quantities where the differences between the radiosonde types are much smaller than the variability in a single profile.

For the purposes of calculating quantitative differences between the soundings, we interpolate the RS92 profiles to the same time step as the RS41 and then, using the RS41 GPS-derived heights, onto a common vertical grid with $10 \mathrm{~m}$ vertical resolution. Table 7 summarizes the differences between the RS92 and RS41 measurements over all flights and heights. For all of the measured variables, the biases and root mean square differences are smaller than the uncertainties defined in Tables 2-4. Figure 8 shows a summary of the vertical profiles of differences in barometric pressure, dry-bulb temperature, relative humidity, zonal wind speed, and meridional wind speed between the RS92 and RS41 measurements. For each quantity we plot the median, 2575th percentile, and 10-90th percentile difference over all 20 soundings for each height on the interpolated grid. The RS41-calculated pressure is greater than that observed by the RS92 at all heights (Fig. 8a) for about $30 \%$ of the observations. The absolute value of the difference exceeds $0.6 \mathrm{hPa}$ 

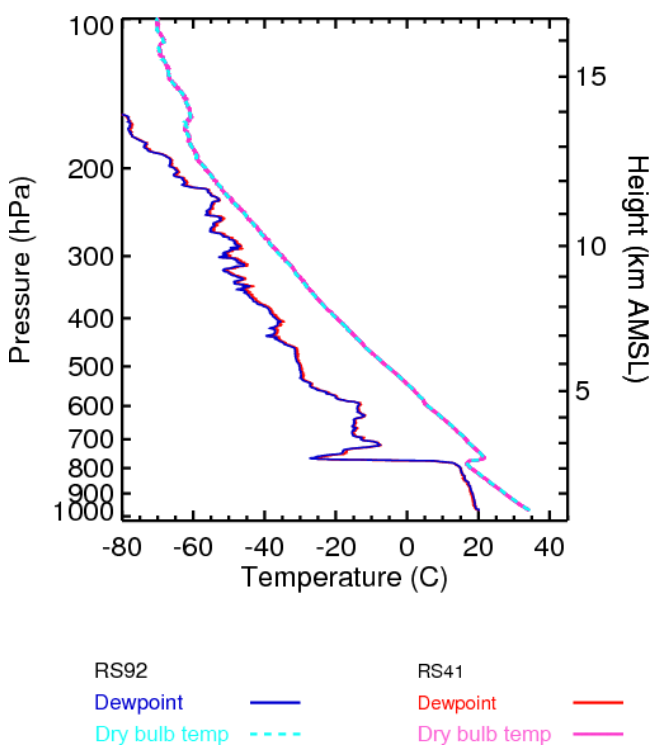

Figure 7. Profiles of dry-bulb and dew point temperature from balloon flight no. 3, which was launched on 3 June 2014 at 17:46 LT. Dry-bulb temperature for RS92 (cyan) and RS41 (magenta). Dew point temperature for RS92 (blue) and RS41 (red).

Table 7. Summary statistics over all sounding flights and heights. The bias difference is defined as RS92-RS41.

\begin{tabular}{lrr}
\hline Variable & $\begin{array}{r}\text { Bias } \\
\text { (RS92 }- \text { RS41) }\end{array}$ & $\begin{array}{r}\text { rms } \\
\text { difference }\end{array}$ \\
\hline Temperature $\left({ }^{\circ} \mathrm{C}\right)$ & -0.0163 & 0.2079 \\
Pressure $(\mathrm{hPa})$ & 0.2208 & 0.4090 \\
$\left(P_{\mathrm{RS} 92}>100 \mathrm{hPa}\right)$ & & \\
Pressure $(\mathrm{hPa})$ & 0.0046 & 0.0822 \\
$\left(P_{\mathrm{RS} 92}<100 \mathrm{hPa}\right)$ & & \\
Relative humidity $(\%)$ & -0.4040 & 1.7225 \\
Zonal wind speed $\left(\mathrm{m} \mathrm{s}^{-1}\right)$ & 0.0043 & 0.1841 \\
Meridonal wind speed $\left(\mathrm{m} \mathrm{s}^{-1}\right)$ & 0.0008 & 0.2026 \\
\hline
\end{tabular}

rms: root mean square.

(the combined uncertainty for both for RS92 sonde at pressure $<100 \mathrm{hPa}$; see Table 4 ) for only $6.42 \%$ of the measurements and exceeds $1.0 \mathrm{hPa}$ (the combined uncertainty for both sonde types at pressure $>100 \mathrm{hPa}$; see Table 4 ) for only $2.26 \%$ of the measurements. This results in a significant minimum in the median difference (RS92 - RS41) of $-0.12 \mathrm{hPa}$ at a height of $0.67 \mathrm{~km}$, with an increasing trend to a value of $0.45 \mathrm{hPa}$ at height of $5.54 \mathrm{~km}$ and then a general decreasing trend through the depth of the atmosphere. These differences are consistent with the results of Motl (2014), who reported a maximum difference of $0.3 \mathrm{hPa}$ decreasing to zero at higher levels.

For dry-bulb temperature (Fig. 8b), the median difference as a function of height does not exceed $0.13{ }^{\circ} \mathrm{C}$ below $28 \mathrm{~km}$. This is consistent with the results of Jauhiainen et al. (2014), who showed mean differences did not exceed $0.2^{\circ} \mathrm{C}$ dur-
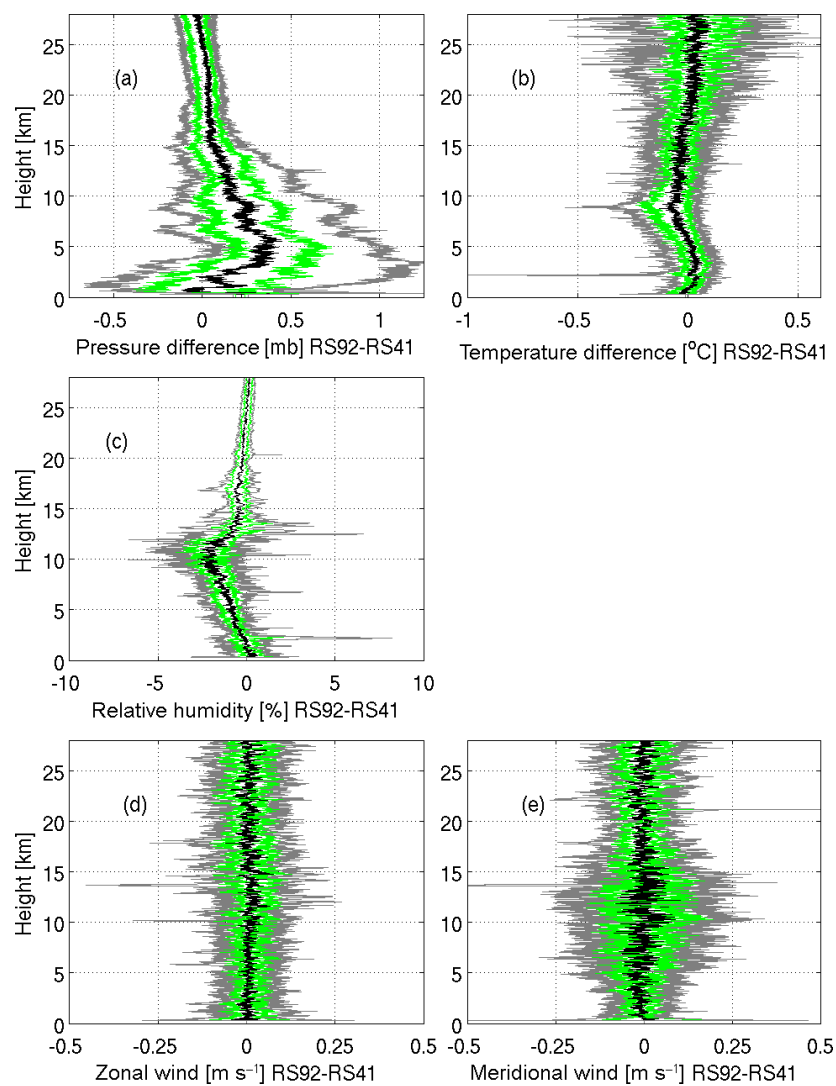

Figure 8. Vertical profiles of the median (black), 25-75th percentile (green), and 10-90th percentile (grey) differences between RS92 and RS41 observations (RS92-RS41) for (a) pressure, (b) dry-bulb temperature, (c) relative humidity, (d) zonal wind, and (e) meridional wind.

ing their sounding intercomparison in the Czech Republic. When all of the temperature observations at all heights are considered, the mean difference is $-0.014{ }^{\circ} \mathrm{C}$. The absolute value of the difference exceeds $0.5^{\circ} \mathrm{C}$ (the combined uncertainty in RS92 temperature measurements; see Table 2) for only $0.59 \%$ of the observations. The large negative temperature difference (RS41 temperature greater than RS92 temperature) in the 10th-percentile curve at $2.2 \mathrm{~km}$ comes from flights no. 9 and 10. Sixty-seven percent of the RS41 observations below $28 \mathrm{~km}$ indicate a larger relative humidity compared to the RS92 (Fig. 8c), with over $90 \%$ of the observations agreeing to within $2 \% \mathrm{RH}$. The peak in the median differences occurs near $10 \mathrm{~km}$. At $2.2 \mathrm{~km}$ there is again a noticeable feature where the RS41 measurement is significantly moister $(8.2 \%)$ than the RS92 that comes from soundings 9 and 10 .

Figures 9 and 10 are used to examine the details of the differences during these two flights. For both soundings, the RS92 shows a cooler temperature (Fig. 9b, d) and larger relative humidity (Fig. 9a, c) compared to the RS41 at heights of approximately $2.1-2.3 \mathrm{~km}$. Figure 10 indicates that there 

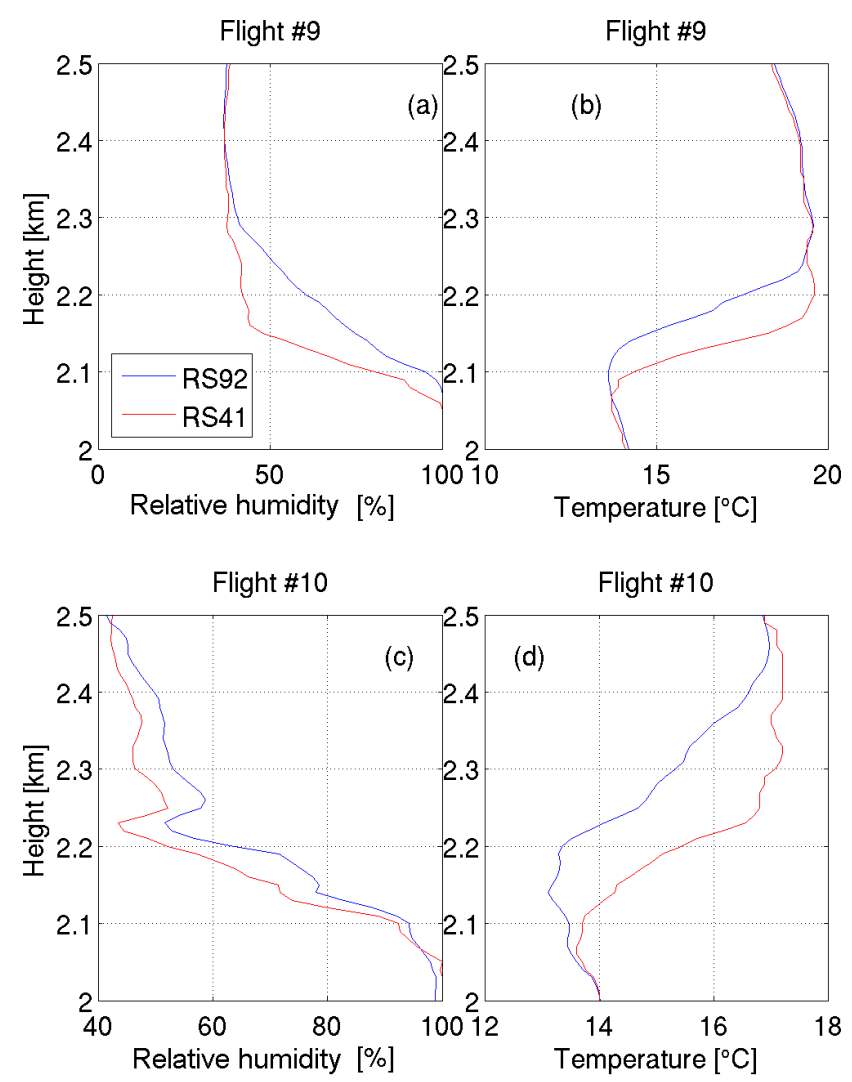

Figure 9. Comparison of relative humidity $(\mathbf{a}, \mathbf{c})$ and dry-bulb temperature (b, d) from flight no. 9 (top), launch time 5 June 2014 14:50 UTC, and flight no. 10 (bottom), launch time 5 June 2014 16:34 UTC.

is a liquid cloud layer with a cloud top height near $2.1 \mathrm{~km}$ most noticeable after 15:00 UTC but also present during intermittent precipitation prior to that. The large temperature (and relative humidity) differences are occurring shortly after passing through the cloud layer into a dry atmospheric layer that begins at approximately $2.1 \mathrm{~km}$. The additional cooling of the RS92 is likely due to the "wet-bulbing" effect whereby the RS92 sensor has become wet as it passed through the cloud layer and then is subject to evaporative cooling after entering the dry layer above cloud. Both the RS92 and RS41 radiosondes use a hydrophobic coating on the temperature sensor in order to reduce the wet-bulbing effect without impacting the temperature measurements. However, it seems that in the RS92 humidity measurement the applied sequential pulse heating method with relatively long non-heating periods may not be sufficient to eliminate sensor icing/wetting in some cloud conditions. For these two sounding flights, the RS41 measurements seem to have less impact from wet-bulbing effects compared to the RS92, consistent with the results of Edwards et al. (2014).

Figure $8 \mathrm{~d}$ and e show the observed differences for the zonal and meridional wind profiles. The differences in the zonal wind measurements are not statistically significant,

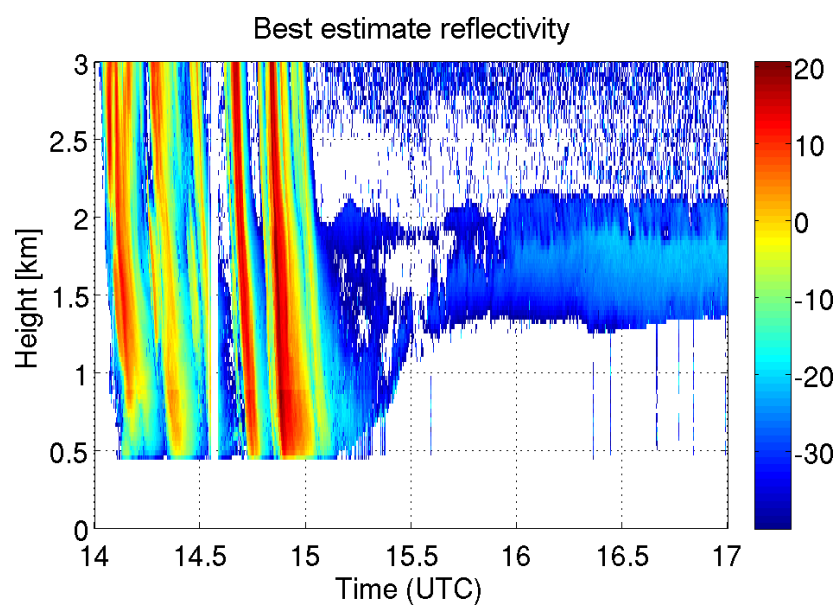

Figure 10. Best-estimate radar reflectivity (bottom) from the Ka-band ARM zenith-pointing Radar Active Remote Sensing of CLouds (ARSCL) product for 5 June 2014.

while the differences in the meridional winds are statistically significant (though still small). Both the zonal and meridional wind speeds agree within $0.5 \mathrm{~m} \mathrm{~s}^{-1}$ for all soundings at all heights. This is consistent with the results of Motl (2014), who found differences in the wind velocities to be less than $0.1 \mathrm{~m} \mathrm{~s}^{-1}$ for all levels. The larger (but still rather small) differences in the meridional wind speeds compared to the zonal wind speeds, particularly in the $5-10 \mathrm{~km}$ height range, are the result of the prevailing winds being westerly (near $270^{\circ}$ ) at these heights, where the cosine dependence of the meridional wind has the largest rate of change, and so a small difference in wind direction will propagate to a larger difference in the wind speed. This agreement is not unexpected as the RS92 and RS41 use the same technique to derive winds from GPS location observations.

The overall differences in pressure, dry-bulb temperature, relative humidity, and wind speeds observed during this study are consistent with those quantified by Motl (2014), Edwards et al. (2014), and Jauhiainen et al. (2014). The relative peaks in the temperature and relative humidity differences near a height of $10 \mathrm{~km}$ may be related to a combination of sensor calibration, differences in radiative heating impacts (measurements plus correction algorithms) of sensors due to contributions from cloud albedo, and sensor response time in regions of strong gradients as the sondes traverse cloud layers.

Solar heating of the radiosonde sensors has been known to have an impact on radiosonde measurements (e.g., Vömel et al., 2007; Rowe et al., 2008; Milosevich et al., 2009; Immler et al., 2010; Wang et al., 2013; Dirksen et al., 2014). In order to investigate solar heating impacts on the differences between RS92 and RS41 radiosondes, we have computed the differences separately for daytime and nighttime soundings (as indicated in Table 5). Figure 11 shows the profiles of the median differences in pressure, dry-bulb temper- 

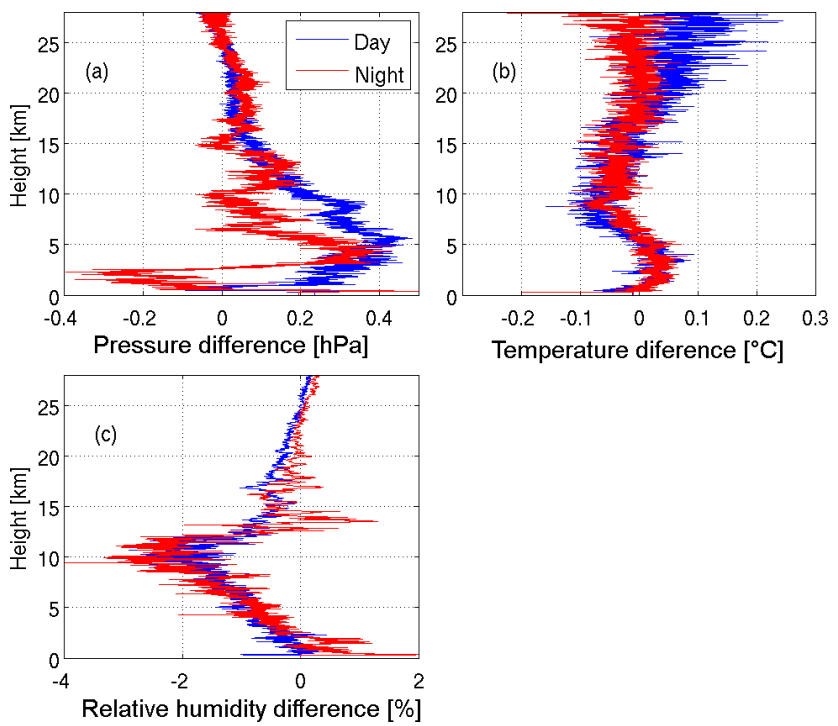

Figure 11. Differences between RS92 and RS41 radiosondes (RS92 - RS41) for daytime (blue) and nighttime (red) flights for (a) pressure, (b) temperature, and (c) relative humidity.

ature, and humidity for daytime (blue) and nighttime (red) soundings. Note that there were only 6 nighttime and 14 daytime soundings during the intercomparison and that, due to the notable difference in sample sizes, the levels of noisiness in the nighttime-daytime median difference profiles are not directly comparable. The pressure profiles show distinct differences between day and night, with daytime soundings showing negative values $\left(P_{\mathrm{RS} 41}>P_{\mathrm{RS} 92}\right)$ below $1 \mathrm{~km}$, followed by positive values to $23 \mathrm{~km}$ and near zero above that. Nighttime soundings show larger negative values in the lower atmosphere (below $3 \mathrm{~km}$ ), but then a secondary negative peaks near 9 and $15 \mathrm{~km}$. The temperature difference profiles are nearly identical with slightly larger differences $\left(T_{\mathrm{RS} 41}>\right.$ $T_{\mathrm{RS} 92}$ ) during the daytime between 5 and $10 \mathrm{~km}$, and then larger differences in the other direction $\left(T_{\mathrm{RS} 92}>T_{\mathrm{RS} 41}\right)$ above approximately $15 \mathrm{~km}$. The temperature measurements of both sondes are corrected using the same principles but separate algorithms. The differences in the solar radiation corrections (degrees subtracted from the measured temperature) differ (RS92 - RS41) from -0.82 to $0.05^{\circ} \mathrm{C}$ depending on the atmospheric pressure and the solar zenith angle (Vaisala, 2013; www.vaisala.com). The differences in temperature presented in Fig. 11, and elsewhere, are a combination of the differences in the direct measurements and the radiation correction schemes. In many instances, particularly at high solar elevation angles and low pressure, the differences in the radiation correction schemes can be the dominant contribution to these differences. For the pressure levels in our comparisons the solar radiation corrections (degrees subtracted from measured temperature) differ (RS92-RS41) from -0.59 to $0.05^{\circ} \mathrm{C}$ depending on the solar elevation angle. In total, 85 (90) \% of the daytime (nighttime) tempera-

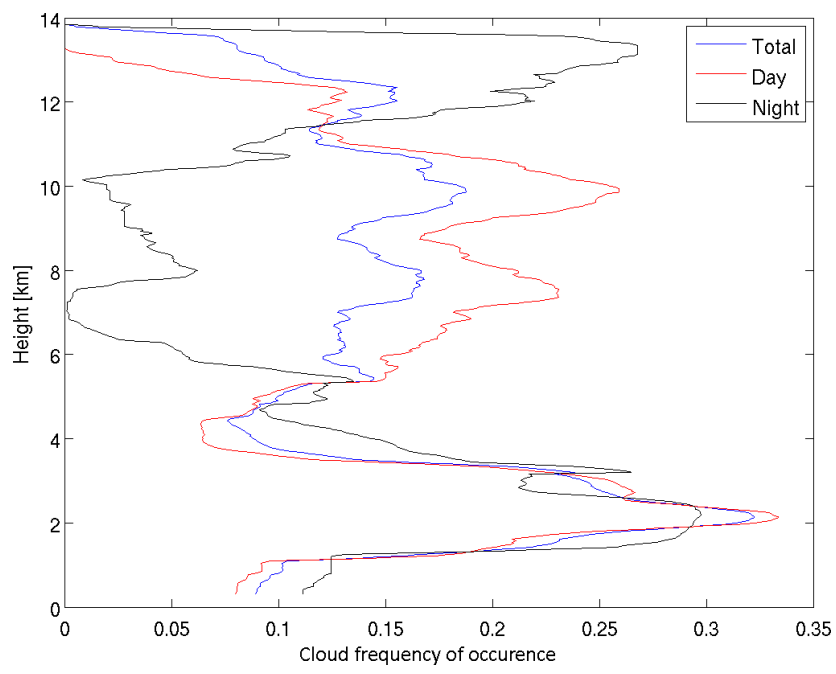

Figure 12. Comparison of cloud frequency of occurrence for daytime, nighttime, and all sounding launch times. Cloud frequency of occurrence is calculated using the ARSCL product and compiled over a $1 \mathrm{~h}$ window following each sonde launch time.

ture observations agree within $0.2^{\circ} \mathrm{C}$. These results are consistent with the results of Motl (2014) and Jauhiainen et al. (2014), who concluded that the daytime temperature differences were higher compared to nighttime but still generally less than $0.2{ }^{\circ} \mathrm{C}$. The daytime-nighttime differences in median relative humidity generally agree within $1 \%(94 \%$ of heights), with the $\mathrm{RH}_{\mathrm{RS} 41}$ almost always greater than the $\mathrm{RH}_{\mathrm{RS} 92}$, showing slightly smaller differences during the nighttime, compared to the daytime, below approximately $5 \mathrm{~km}$ and above approximately $12 \mathrm{~km}$ (with $\mathrm{RH}_{\mathrm{RS} 92}$ sometimes exceeding $\left.\mathrm{RH}_{\mathrm{RS} 41}\right)$. The day-night differences in temperature and relative humidity (combined measurements and corrections) will also propagate to small differences in the GPS-based pressure measurements (Fig. 11a) as these are used to determine the air density and subsequently the pressure. It must be noted that clouds, notably differences in the occurrences for daytime and nighttime observations, could be driving the observed differences in all of the measurements. Figure 12 shows profiles of the cloud frequency of occurrence compiled over the hour during which a sounding launch occurred for daytime, nighttime, and all launches. Both daytime and nighttime profiles include a low-level peak near $2 \mathrm{~km}$. When interpreting Fig. 11 (and Figs. 13-16), the covariance of the diurnal cycle, cloudiness profiles and atmospheric state cannot be ignored. The day-night differences in cloud occurrence will certainly contribute to the differences in temperature and humidity measurements shown in Fig. 11. However, comparisons of individual profiles of daytime and nighttime soundings under similar cloud conditions (not shown) indicate that the day/night differences are persistent. 
Table 8. Simple cloud classifications for radiosonde flight times. Based on hourly cloud frequency of occurrence at radiosonde launch time from the ARSCL data product. The "Layers with clouds" column is based on low $<3 \mathrm{~km}, 3<$ middle $<8 \mathrm{~km}$, high $>8 \mathrm{~km}$.

\begin{tabular}{lll}
\hline Category & Sounding flight number(s) & Layers with cloud \\
\hline 1 & $11,13^{*}$ & Low \\
2 & $16,17,18,19^{*}$ & Low, middle \\
3 & $1,2,3,7,8,20^{*}$ & Low, high \\
4 & $9,10,12^{*}, 14$ & Low, middle, high \\
5 & 6 & Middle \\
6 & 15 & Middle, high \\
7 & $4^{*}, 5^{*}$ & High \\
\hline
\end{tabular}

* Nighttime sounding flights.

In order to further quantify the impact of clouds on the observed differences between the RS41 and RS92 radiosondes, we categorize the sounding flights by the observed cloud conditions (cc no.) based on ARSCL-derived profiles of cloud frequency of occurrence during the hour of the sounding launch. We define seven broad cloud categories for the sounding times, summarized in Table 8 . These cloud categories are formulated based on the presence (or not) of clouds in three layers: low $(<3 \mathrm{~km})$, middle (between 3 and $8 \mathrm{~km}$ ), and high $(>8 \mathrm{~km})$. Of these seven categories, three (nos. 2 , 3,4 ) have three or more daytime sounding flights. We limit our analysis of the radiosonde differences as a function of cloud categories to these three categories. The differences in pressure between the RS92 and RS41 radiosonde measurements show little dependence on the cloud conditions (not shown). Figure 13 shows the differences in temperature between the RS92 and RS41 radiosonde measurements broken down into these three categories. Cloud categories cc2 (low + middle) and cc4 (low + middle + high) show very similar differences. The large negative difference in cc4 at a height of approximately $2.1 \mathrm{~km}$ is the wet-bulbing signature we identified in Figs. 8-10. Category no. 3 shows a larger difference (RS41 > RS92) for heights between 5 and $15 \mathrm{~km}$, peaking near $10 \mathrm{~km}$. One possible explanation for the larger (but still small) difference at these heights is an increased solar heating impact from a combination of direct solar radiation and reflected solar radiation from the lower cloud layer that is not accounted for as well in the RS92 measurements and correction algorithms.

In order to investigate other environmental factors that may impact the radiosonde observations, we partition the comparison statistics by independent measurements of the precipitable water vapor (PWV) retrieved from microwave radiometer measurements, sky cover (SC) measured by a total sky imager, and surface $\mathrm{RH}$ and surface temperature from in situ surface meteorology sensors. For these comparisons we partition the radiosonde observations based on the median of the independent measurements at the 20 launch
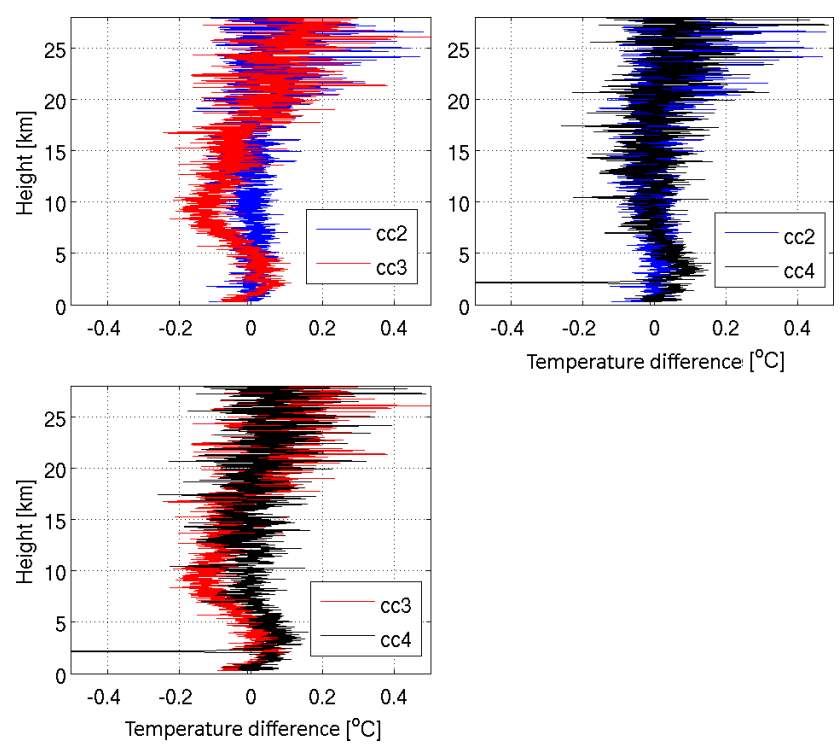

Figure 13. Temperature differences between RS92 and RS41 radiosondes (RS92 - RS41) for three different cloud categories (cc no.) summarized in Table 7. Only those cloud categories for which there were three or more daytime flights are included.
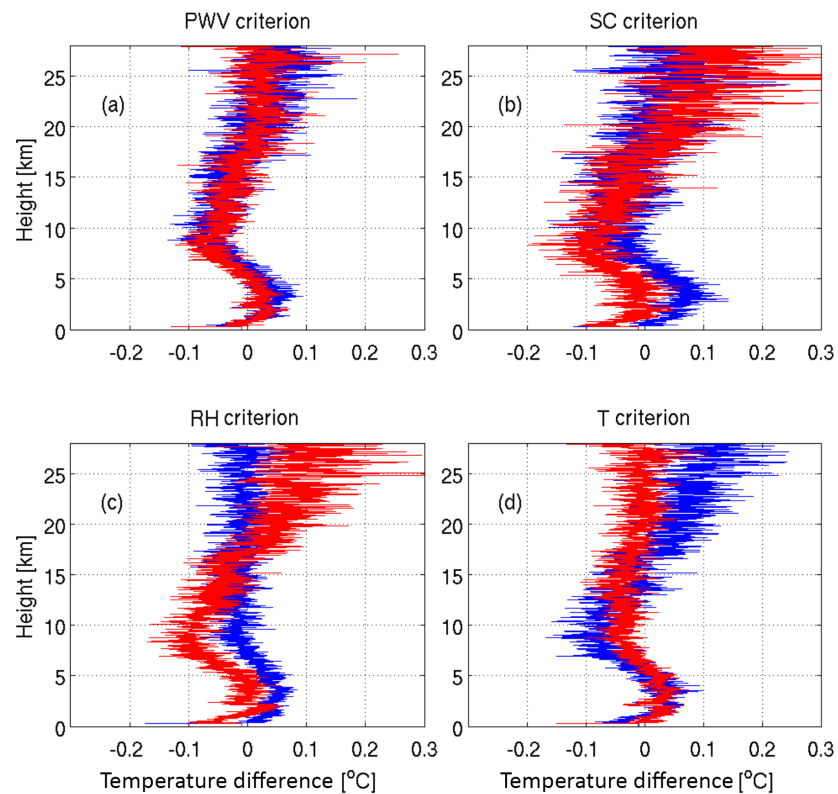

Figure 14. Temperature difference between RS92 and RS41 radiosondes (RS92-RS41) as a function of height for sonde launches with (a) $\mathrm{PWV}>3.63 \mathrm{~cm}$ (blue) and those with $\mathrm{PWV}<3.63 \mathrm{~cm}$ (red), (b) $\mathrm{SC}>41.45 \%$ (blue) and $\mathrm{SC}<41.45 \%$ (red), (c) surface $\mathrm{RH}>65 \%$ (blue) and surface $\mathrm{RH}<65 \%$ (red), and (d) surface temperature $>26.2{ }^{\circ} \mathrm{C}$ and surface temperature $<26.2^{\circ} \mathrm{C}$ (red). The PWV, SC, RH, and $T=$ of $3.63 \mathrm{~cm}$, $41.45 \%, 65 \%$, and $26.2{ }^{\circ} \mathrm{C}$, respectively, are based on the median values for the 20 balloon launches during the intercomparison. 

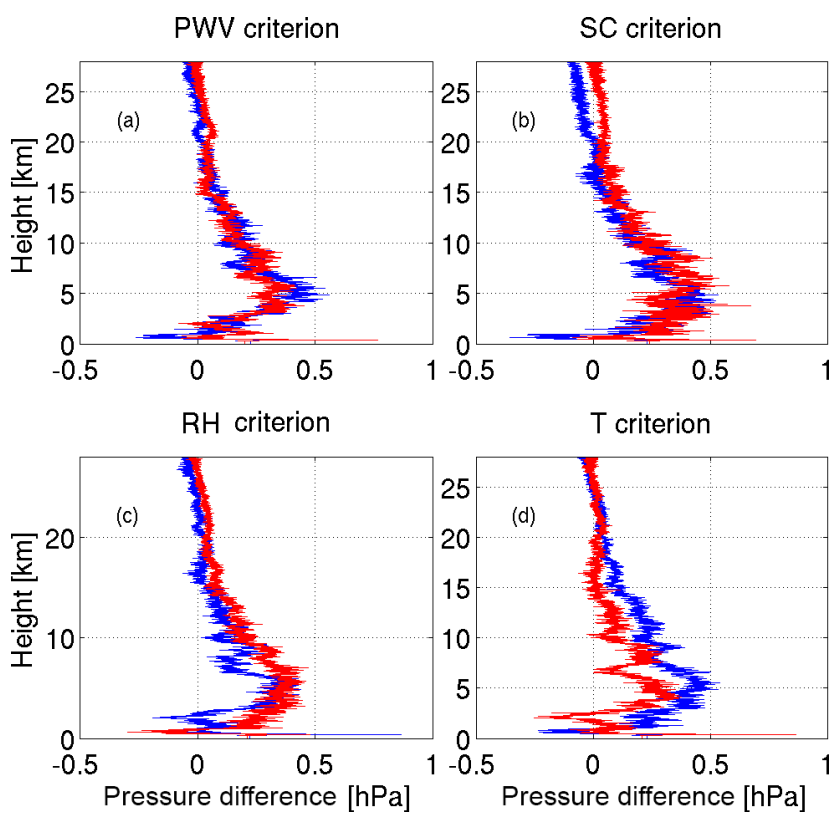

Figure 15. Same as Fig. 14 but for pressure differences.
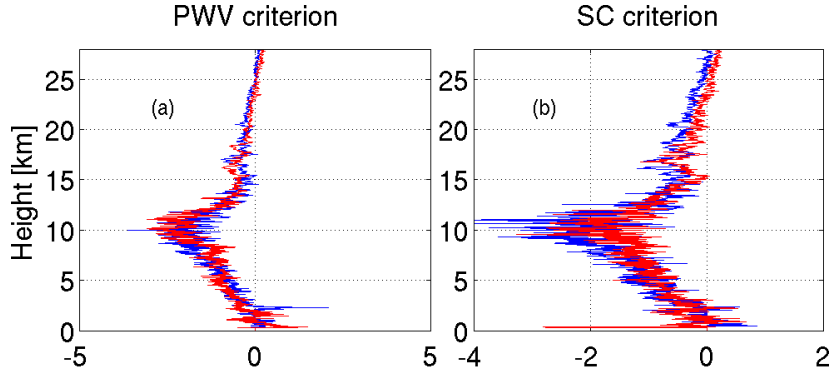

$\mathrm{RH}$ criterion
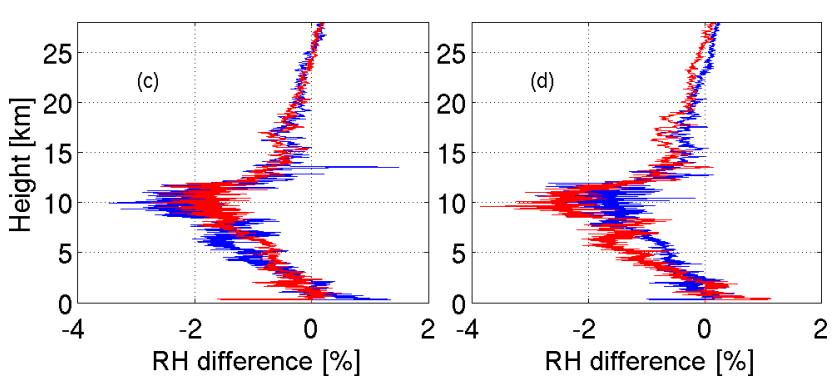

Figure 16. Same as Fig. 14 but for relative humidity differences.

times: $3.63 \mathrm{~cm}$ for PWV, $41.45 \%$ for sky cover, $65 \%$ for surface $\mathrm{RH}$, and $26.2^{\circ} \mathrm{C}$ for surface temperature. Figure 14 shows this comparison for median profiles of dry-bulb temperature differences. The median profiles of dry-bulb temperature differences show little sensitivity to the environmental PWV (Fig. 14a). The profiles for the lowest and highest PWVs match very closely. For $99 \%$ of the heights, the median temperature differences for the highest and lowest PWV agree to within $0.02{ }^{\circ} \mathrm{C}$. When partitioning the difference profiles by sky cover observations, it should be noted that the TSI does not report sky cover at night, so the nighttime radiosonde flights are not included in this plot (Fig. 14b). Below approximately $10 \mathrm{~km}$ the difference between the RS41 and RS92 observations is slightly more $\left(T_{\mathrm{RS} 41}>T_{\mathrm{RS} 92}\right)$ for radiosonde flights during lower sky cover $(\mathrm{SC}<40 \%)$ conditions compared to higher sky cover (SC $>40 \%$ ) conditions. This difference, in the same direction as the differences between daytime and nighttime observations (Fig. 11), is likely the result of differences in solar heating impacts on the radiosonde measurements when clouds are present. This conclusion is further supported by the fact that, once above the tropopause, the differences between the two curves become much smaller. Figure $14 \mathrm{c}$ and d show the comparisons partitioned by the surface RH and surface temperature, respectively. Consistent with Fig. 14b, for conditions where less cloudiness would be expected (lower surface RH and correspondingly higher surface temperature) there are larger differences $\left(T_{\mathrm{RS} 41}>T_{\mathrm{RS} 92}\right)$ in the troposphere. Figures 15 and 16 show similar comparisons for pressure and relative humidity differences, respectively. The pressure differences show little dependence on the PWV and SC. There are some different behaviors when partitioning by surface thermodynamic variables. Larger differences $\left(P_{\mathrm{RS} 92}-P_{\mathrm{RS} 41}\right)$ are seen when the surface relative humidity (temperature) is larger (lower). The RH differences show less sensitivity to the environmental parameters.

Differences between the radiosonde observations may be magnified in certain temperature and/or humidity ranges. In an effort to evaluate this possibility, we evaluate the differences in relative humidity as a function of temperature for four different humidity ranges (Fig. 17). We determine the median $\mathrm{RH}$ difference $\left(\mathrm{RH}_{\mathrm{RS} 92}-\mathrm{RH}_{\mathrm{RS} 41}\right)$ for all measurements that fall within a $20 \% \mathrm{RH}$ and $10^{\circ} \mathrm{C}$ temperature bin, requiring a minimum of 250 measurements from at least 6 different flights in a given bin. With the exception of a small number of points in the $0-20 \% \mathrm{RH}$ range and temperatures of -40 to -42 , the RS41 shows a higher mean relative humidity compared to the RS92 for all humidity ranges and all temperatures. At low relative humidity $(0$ $20 \%$ ) the difference between the two radiosonde types increases with temperature $\left(\mathrm{RH}_{41}>\mathrm{RH}_{92}\right)$ to approximately $-25^{\circ} \mathrm{C}$, where the difference is $-1.1 \%$. The difference then decreases to a temperature of $-45^{\circ} \mathrm{C}$, where RH92 $>$ RH41 by $0.1 \%$. Finally the difference increases to lower temperatures $\left(\mathrm{RH}_{41}>\mathrm{RH}_{92}\right)$. In the other three $\mathrm{RH}$ ranges $(20-40$, $40-60,60-80 \%)$, there is a consistent trend of the difference increasing with temperature to $-40^{\circ} \mathrm{C}$ and then decreasing to colder temperatures. This difference has a maximum of nearly $2.5 \% \mathrm{RH}$ at $-35^{\circ} \mathrm{C}$ for $\mathrm{RH}$ in the range of $40-60 \%$. These differences are similar in magnitude to those observed by Edwards et al. (2014).

A benefit of performing this intercomparison at the ARM SGP site is the ability to leverage the other measurements that are available. We have already used these observations to 


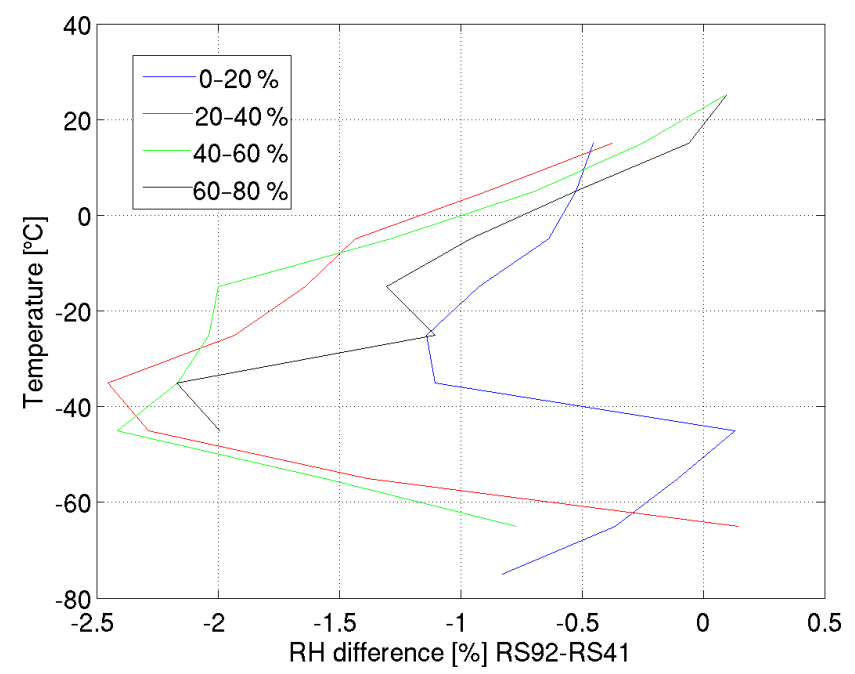

Figure 17. Median difference in relative humidity between the RS92 and RS41 radiosondes as a function of temperature for four different relative humidity ranges.

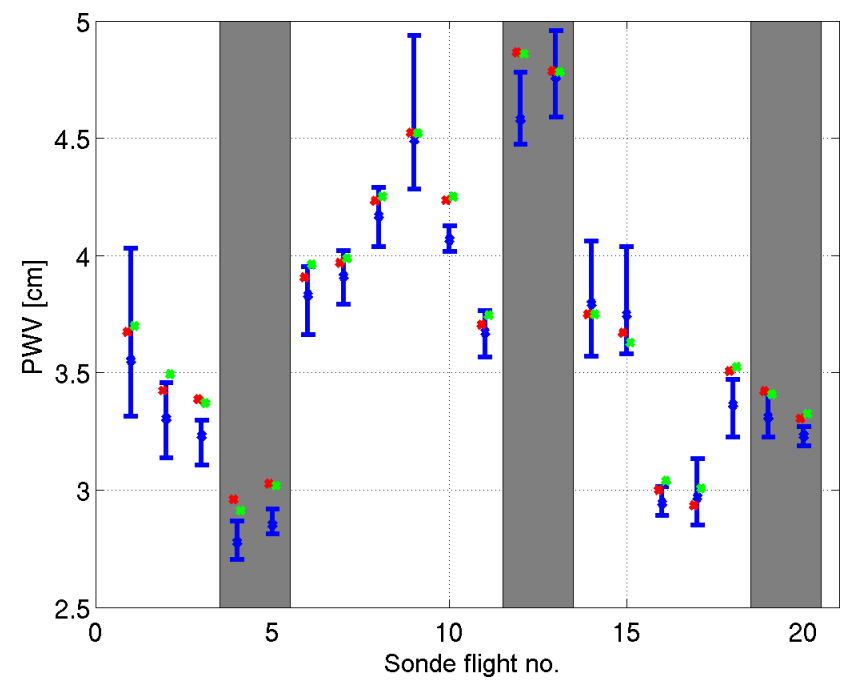

Figure 18. Comparison of precipitable water vapor for the RS92 (red), RS41 (green), and microwave radiometer (blue). Bars on the MWR observations represent the range of observed PWV during the first half hour of each balloon launch. Gray shading indicates nighttime sounding flights.

classify the atmospheric state and cloud conditions for partitioning statistics in the radiosonde comparisons. Here we use retrieved estimates of PWV from a microwave radiometer as an independent standard to compare the radiosonde observations. Figure 18 shows a comparison of PWV for the RS92 (red), RS41 (green), and microwave radiometer (blue) for each radiosonde flight. Bars on the MWR observations represent the range of observed PWV during the first half hour (since the bulk of the water vapor will be in the lower troposphere) of each balloon flight. The PWV is re- trieved from the MWR measurements, using an optimal estimation algorithm (Turner et al., 2007; Cadeddu et al., 2013) from which uncertainties are computed from the posterior covariance matrix for each observation time step. Over the course of the radiosonde intercomparison, the uncertainty in the MWR-retrieved PWV ranged from 0.0353 to $0.0440 \mathrm{~cm}$ with a median value of $0.0356 \mathrm{~cm}$. These values are much smaller than the variability during the first half hour of each plot that is shown in Fig. 18. Several previous comparisons between PWV calculated from radiosonde, MWR, and GPS observations have shown general agreement within 1-2 mm (Emardson et al., 2000; Niell et al., 2001; Li et al., 2003; Garcia-Lorenz et al., 2009). For all but three flights (nos. 14, $15,17)$ the PWV calculated from both soundings is greater than the mean PWV over the first half hour of the flight calculated from the MWR retrieval. This is not unusual and has been observed previously at the SGP (Jensen et al., 2015) and at the ARM site at Manus, Papua New Guinea (Ciesielski et al., 2014). These differences do not correlate with observed cloud cover, surface wind speed/direction, humidity, or PWV. It appears that non-local variability in soil moisture and low-level humidity are contributing significantly to the sonde PWV estimates. The Oklahoma Climatological Survey report for June 2014 (Oklahoma Climatological Survey, 2014) shows the SGP site near the edge of a strong gradient in soil moisture, with much larger values to the northeast of the SGP site. Most, but not all, of the radiosonde flights traveled to the northeast of the site over the lowest $2 \mathrm{~km}$ of their flight and likely experienced higher humidity values than over the SGP site. Previous comparison studies done in much drier conditions (Survo et al., 2015) showed slightly lower PWV measurements from the MWR compared to both the RS41 and RS92 radiosondes. For 10 (8) of the flights the PWV calculated from the RS41 (RS92) is greater than the largest PWV retrieved from the MWR over the first half hour of the flight. The PWV from the RS41 exceeds that from the RS92 for 11 of the flights, with the differences $\left(\mathrm{PWV}_{\mathrm{RS} 92}-\mathrm{PWV}_{\mathrm{RS41}}\right)$ ranging from -0.73 to $+0.48 \mathrm{~mm}$. This agreement is well within the RS92 PWV uncertainty of $\pm 2 \mathrm{~mm}$ (Yu et al., 2015) based on Global Climate Observing System (GCOS) Reference Upper-Air Network (GRUAN) RH uncertainly estimates.

\section{Summary and conclusions}

The Vaisala RS41 radiosonde was developed to replace the RS92 radiosonde, aimed at improving the accuracy of measurements of profiles of atmospheric temperature, humidity, and pressure. In order to help characterize these improvements, an intercomparison campaign was undertaken at the ARM SGP site in north-central Oklahoma, USA, during June 2014. During this campaign, a total of 20 dual radiosonde flights were performed in a variety of atmospheric conditions representing typical midlatitude continental sum- 
mertime conditions. The results show that for most of the observed conditions the RS92 and RS41 measurements agree much better than the manufacturer-specified combined uncertainties with notable exceptions when exiting liquid cloud layers where the wet-bulbing effect appears to be mitigated for several cases in the RS41 observations. The RS41 measurements of temperature and humidity, with applied correction algorithms, also appear to show less sensitivity to solar heating. These results suggest that the RS41 does provide important improvements, particularly in cloudy conditions. For many science applications - such as atmospheric process studies, retrieval development, and weather forecasting and climate modeling - the described differences between the RS92 and RS41 measurements will have little impact. However, for long-term trend analysis of thermodynamic quantities and other climate applications, additional characterization of the RS41 measurements and their relation to the longterm observational records will be required.

\section{Data availability}

The sounding dataset collected during this intercomparison (Jensen and Toto, 2014) is available from the ARM PI data archive (http://www.arm.gov/data/pi). All other ARM datasets (those used in the analysis and others) are available from the ARM archive (www.archive.arm.gov) and can be found using the ARM data discovery tool (Kyrouac, 2005; Morris, 2000; Johnson et al., 2015; Gaustad and Riihimaki, 1996).

Acknowledgements. Participation by M. Jensen, D. Holdridge, T. Toto, and K. Johnson was funded by the DOE ARM program. S. Baxter was supported by the DOE, Office of Science, and Office of Workforce Development for Teachers and Scientists (WDTS) under the Science Undergaduate Laboratory Internship (SULI) Program. Data were obtained from the ARM program sponsored by the US Department of Energy, Office of Science, Office of Biological and Environmental Research, Climate and Environmental Sciences Division. The DOE ARM program provided RS92 radiosondes, balloons, unwinders, and parachutes. We thank David Turner (NSSL) for discussion regarding PWV measurements from the MWR and radiosondes. We would also like to acknowledge the technical support from ARM SGP Central Facility operations staff, logistical support from the BNL Office of Educational Programs, and support in campaign arrangements from Vaisala.

Edited by: L. Bianco

Reviewed by: three anonymous referees

\section{References}

Ackerman, T. P. and Stokes, G. M.: The Atmospheric Radiation Measurement Program, Physics Today, 56 38-45, 2003.

Bodeker, G. E., Bojinski, S., Cimini, D., Dirksen, R. J., Haeffelin, M., Hannigan, J. W., Hurst, D. F., Leblanc, T., Madonna, F., Maturilli, M., Mikalsen, A. C., Philipona, R., Reale, T., Seidel, D. J., Tan, D. G. H., Thorne, P. W., Vomel, H., and Wang, J.: Reference upper-air observations for climate: From concept to reality, B. Am. Meteorol. Soc., 97, 123-135, doi:10.1175/BAMS-D-14$00072.1,2016$.

Cadeddu, M. P., Liljegren, J. C., and Turner, D. D.: The Atmospheric radiation measurement (ARM) program network of microwave radiometers: instrumentation, data, and retrievals, Atmos. Meas. Tech., 6, 2359-2372, doi:10.5194/amt-6-2359-2013, 2013.

Ciesielski, P. E, Yu, H., Johnson, R. H., Yoneyama, K., Katsumata, M., Long, C. N., Wang, J., Loehrer, S. M., Young, K., Williams, S. F., Brown, W., Braun, J., and Van Hove, T.: Quality controlled upper-air sounding dataset for DYNAMO/CINDY/AMIE: development and corrections, J. Atmos. Ocean. Tech., 31, 741-764, 2014.

Clothiaux, E. E., Ackerman, T. P., Mace, G. G., Moran, K. P., Marchand, R. T., Miller, M. A., and Martner, B. E.: Objective determination of cloud heights and radar reflectivities using a combination of active remote sensors at the ARM CART sites, J. Appl. Meteorol., 39, 645-665, 2000.

Dai, A., Wang, J., Thorne, P. W., Parker, D. E., Haimberger, L., and Wang, X. L.: A New Approach to Homogenize Daily Radiosonde Humidity Data, J. Climate, 24, 965-991, 2010.

Dirksen, R. J., Sommer, M., Immler, F. J., Hurst, D. F., Kivi, R., and Vömel, H.: Reference quality upper-air measurements: GRUAN data processing for the Vaisala RS92 radiosonde, Atmos. Meas. Tech., 7, 4463-4490, doi:10.5194/amt-7-4463-2014, 2014.

Dunn, M., Johnson, K. L., and Jensen, M. P.: The Microbase ValueAdded Product: A Baseline Retrieval of Cloud Microphysical Properties, US Department of Energy, Office of Science, Office of Biological and Environmental Research, Gaithersburg, MD, USA, DOE/SC-ARM/TR-095, 2011.

Edwards, Anderson, D. G., Oakley, T., and Gault, P.: Met Office Intercomparison of Vaisala RS92 and RS41 Radiosondes, Met Office, Exeter, UK, Met Office Report, 89 pp., 2014.

Elliott, W. P. and Gaffen, D. J.: On the utility of radiosonde humidity archives for climate studies, B. Am. Meteorol. Soc., 72, 15071520, 1991.

Elliot, W. P., Ross, R. J., and Schwartz, B.: Effects on climate records of changes in national weather service humidity processing procedures, J. Climate, 11, 2424-2436, 1998.

Emardson, T. R., Johansson, J., and Elgered, G.: The systematics behavior of water vapor estimates using four years's of GPS observations, IEEE T. Geosci. Remote, 38, 324-329, 2000.

Gaffen, D. J.: Historical changes in radiosonde instruments and practices, World Meteorological Organization, Geneva, Switzerland, WMO Instruments and Observing Methods Rep., 50, 123 pp., 1993.

Gaustad, K. and Riihimaki, L.: MWR Retrievals (MWRRET), 3 June-8 June $2014,36.605^{\circ} \mathrm{N}, 97.485^{\circ} \mathrm{W}$ : Southern Great Plains Central Facility (C1), ARM Data Archive, Oak Ridge, Tennessee, USA, doi:10.5439/1027369, 1996. 
Garcia-Lorenzo, B., Castro-Almazan, J. A., Eff-Darwich, A., Munoz-Tunon, C., Pinilla-Alonso, N., RodriguesEspinosa, J. M., and Romero, I.: Precipitable water vapour content above the Roque de los Muchachos observatory from GPS estimations, in: Proc. SPIE 7475, Remote Sensing of Clouds and the Atmosphere XIV, 74751H, doi:10.1117/12.830235, 2009.

Ghan, S. J., Randall, D. A., Xu, K.-M., Cederwall, R., Cripe, D., Hack, J., Icobellis, S., Klein, S., Krueger, S. K., Lohmann, U., Pedretti, J., Robock, A., Rotsayn, L., Somerville, R., Stechikov, G., Sud, Y., Walker, G., Xie, S. C., Yio, J., and Zhang, M. H.: An intercomparison of single column model simulations of summertime midlatitude continental convection, J. Geophys. Res., 105, 2091-2124, 2000.

Haimberger, L.: Homogenization of radiosonde temperature time series using innovation statistics, J. Climate, 20, 1377-1403, 2007

Haimberger, L., Tavolato, C., and Sperka, S.: Toward Elimination of the Warm Bias in Historic Radiosonde Temperature Records - Some New Results from a Comprehensive Intercomparison of Upper-Air Data, J. Climate, 21, 4587-4606, doi:10.1175/2008JCLI1929.1, 2008.

Huang, D., Zhao, C., Dunn, M., Dong, X., Mace, G. G., Jensen, M. P., Xie, S., and Liu, Y.: An intercomparison of radarbased liquid cloud microphysics retrievals and implications for model evaluation studies, Atmos. Meas. Tech., 5, 1409-1424, doi:10.5194/amt-5-1409-2012, 2012.

Immler, F. J., Dykema, J., Gardiner, T., Whiteman, D. N., Thorne, P. W., and Vömel, H.: Reference Quality Upper-Air Measurements: guidance for developing GRUAN data products, Atmos. Meas. Tech., 3, 1217-1231, doi:10.5194/amt-3-1217-2010, 2010.

Jauhiainen, H., Survo, P., Lehtinen, R., and Lentonen, J.: Radiosonde RS41 and RS92 key differences and comparison test results in different locations and climates, TECO-2014, WMO Technical Conference on Meteorological and Environmental Instruments and Methods of Observations, Saint Petersberg, Russian Federation, 7-9 July 2014, P3(16), 2014.

Jensen, M. P. and Toto, T.: Soundings from SGP, June 2014 Sounding Intercomparison, 3 June-8 June 2014, 36 $36^{\prime} 18.0^{\prime \prime} \mathrm{N}$, $97^{\circ} 29^{\prime} 6.0^{\prime \prime} \mathrm{W}$ : Southern Great Plains Central Facility Atmospheric Radiation Measurement (ARM) Climate Research Facility Data Archive, Oak Ridge, Tennessee, USA, doi:10.5439/1171962, 2015.

Jensen, M. P., Toto, T., Troyan, D., Ciesielski, P. E., Holdridge, D., Kyrouac, J., Schatz, J., Zhang, Y., and Xie, S.: The Midlatitude Continental Convective Clouds Experiment (MC3E) sounding network: operations, processing and analysis, Atmos. Meas. Tech., 8, 421-434, doi:10.5194/amt-8-421-2015, 2015.

Jensen, M. P., Petersen, W. A., Bansemer, A., Bharadwaj, N., Carey, L. D., Cecil, D. J., Collis, S. M., Del Genio, A. D., Dolan, B., Gerlach, J., Giangrande, S. E., Heymsfield, A., Heymsfield, G. M., Kollias, P., Lang, T. J., Nesbitt, S. W., Neumann, A., Poellot, M. R., Rutledge, S. A., Schwaller, M. R., Tokay, A., Williams, C. R., Wolff, D. B., Xie, S., and Zipser, E. J.: The Midlatitude Continental Convective Clouds Experiment (MC3E), B. Am. Meteorol. Soc., doi:10.1175/BAMS-D-14-00228.1, online first, 2016.

Johnson, K. L., Toto, T., and Jensen, M. P.: KAZR Active RemotelySensed Cloud Locations (KAZRARSCL), 3 June-8 June 2014, $36.605^{\circ} \mathrm{N}, 97.485^{\circ} \mathrm{W}$ : Southern Great Plains Central Facil- ity (C1), ARM Data Archive, Oak Ridge, Tennessee, USA, doi:10.5439/1228768, 2015.

Kollias, P., Miller, M. A., Luke, E. P., Johnson, K. L., Clothiaux, E. E., Moran, K. P., Widener, K. B., and Albrecht, B. A.: The atmospheric radiation measurement program cloud profiling radars: second-generation sampling strategies, processing and cloud data products, J. Atmos. Ocean. Tech., 24, 199-1214, doi:10.1175/JTECH2033.1, 2007.

Kyrouac, J.: Surface Temperature and Humidity Reference System for Sondes (SURTHREF), 3 June-8 June 2014, $36.605^{\circ} \mathrm{N}$, $97.485^{\circ} \mathrm{W}$ : Southern Great Plains Central Facility, ARM Data Archive, Oak Ridge, Tennessee, USA, doi:10.5439/1025285, 2005.

Li, Z., Muller, J.-P., and Cross, P.: Comparison of precipitable water vapor derived from radiosonde, GPS, and moderate-resolution imaging spectroradiometer measurements, J. Geophys. Res., 108, 4651 doi:10.1029/2003JD003372, 2003.

Long, C. N., Slater, D. W., and Tooman, T.: Total Sky Imager Model 880 Status and Testing Results, ARM Technical Report ARM TR-006, US Department of Energy, Washington, DC, 2001.

Mather, J. H. and Voyles, J. W.: The ARM climate research facility: a review of structure and capabilities, B. Am. Meteorol. Soc., 94, 377-392, 2013.

McCarthy, M. P., Thorne, P. W., and Titchner, H. A.: An analysis of tropospheric humidity trends from radiosondes, J. Climate, 22, 5820-5838, 2009.

McFarlane, S., Sivaraman, C., Chapman, E., Jensen, M. P., Toto, T., Liu, S., and Fischer, M.: Planetary Boundary Layer (PBL) Height Value-Added Product (VAP): Radiosonde Retrievals, US Department of Energy, Office of Science, Office of Biological and Environmental Research, Gaithersburg, MD, USA, DOE/SC-ARMTR-132, 2013.

Miller, M. A.: SGP Cloud and Land Surface Interaction Campaign (CLASIC): Science and Implementation Plan US Department of Energy. DOE/SC-ARM-0703, US Department of Energy, Office of Science, Office of Biological and Environmental Research, Gaithersburg, MD, USA, 2007.

Milosevich, L. M., Paukkunen, A., Vomel, H., and Oltmans, S. J.: Development and validation of a time-lag correction for Vaisala radiosonde humidity measurements, J. Atmos. Oceanic Technol., 21, 1305-1237, doi:10.1175/15200426(2004)021<1305:DAVOAT>2.0.CO;2, 2004.

Milosevich, L. M., Vomel, H., Whiteman, D. N., and Leblanc, T.: Accuracy assessment and correction of Vaisala RS92 radiosonde humidity measurements, J. Geophys. Res., 114, D11303, doi:10.1029/2008JD011565, 2009.

Moradi, I., Soden, B., Ferraro, R., Arkin, P., and Vömel, H.: Assessing the quality of humidity measurements from global operational radiosonde sensors, J. Geophys. Res.-Atmos., 118, 80408053, doi:10.1002/jgrd.50589, 2013.

Morris, J.: Climate Research Facility: Total Sky Imager Sky Cover (TSYSKYCOVER), 3 June-8 June 2014, 36.605 N, 97.485 W: Southern Great Plains Central Facility (C1), ARM Data Archive, Oak Ridge, Tennessee, USA, doi:10.5439/1025285, 2000.

Motl, M.: Vaisala RS41 trial in the Czech Republic, Vaisala News, 192, 14-17, 2014.

Nash, J., Oakley, T., Vomel, H., and Wei, L.: WMO Intercomparison of high quality radiosonde systems, Yangjiang, China 12 July3 August 2010, World Meteorological Organization, Geneva, 
Switzerland, WMO Instruments and Observing Methods Report No. 107, 2010.

Niell, A. E., Coster, A. J., Solheim, F. S., Mendes, V. B., Toor, P. C., Langley, R. B., and Upham, C. A.: Comparison of measurements of atmospheric wet delay by radiosonde, water vapor radiometer, GPS, and VLBI, J. Atmos. Ocean. Tech., 18, 830-850, doi:10.1175/1520-0426(2001)018<0830:COMOAW>2.0.CO;2, 2001.

Oklahoma Climatological Survey, 2014: Oklahoma Monthly Climate Summary: June 2014, Board of Regents of the University of Oklahoma, available at: http://climate.ok.gov/summaries/ monthly/2014/MCS_June_2014.pdf, 2014.

Rowe, P. M., Miloshevich, L. M., Turner, D. D., and Walden, V. P.: Dry bias in Vaisala RS90 radiosonde humidity profiles over Antarctica, J. Atmos. Ocean. Tech., 25, 1529-1541, 2008.

Sawyer, V. and Li, Z.: Detection, variations and intercomparison of the planetary boundary layer depth from radiosonde, lidar, and infrared spectrometer, Atmos. Environ., 79, 518-528, doi:10.1016/j.atmosenv.2013.07.019, 2013.

Seidel, D. J., Berger, F. H., Immler, F., Sommer, M., Vömel, H., Diamond, H. J., Dykema, J., Goodrich, D., Murray,W., Peterson, T., Sisterson, D., Thorne, P., and Wang, J.: Reference Upper-Air Observations for Climate: Rationale, Progress, and Plans, B. Am. Meteorol. Soc., 90, 361-369, 2009.

Sherwood, S. C., Meyer, C. L., Allen, R. J., and Titchner, H. A.: Robust tropospheric warming revealed by iteratively homogenized radiosonde data, J. Climate, 21, 5336-5350, 2008.

Stokes, G. M. and Schwartz, S. E.: The Atmospheric Radiation Measurement (ARM) program: programmatic background and design of the cloud and radiation test bed, B. Am. Meteorol. Soc., 75, 1201-1221, 1994.

Survo, P., Leblanc, T., Kivi, R., Jauhiainen, H., and Lehtinen, R.: Comparison of selected in-situ and remote sensing technologies for atmospheric humidity measurement, in: Proceedings of the 19th Conference on Integrated Observing and Assimilation Systems for the Atmosphere, Ocean and Land Surface, Phoenix, AZ, 4-8 January 2015, 13B.2, 2015.

Thorne, P. W., Brohan, P., Titchner, H. A., McCarthy, M. P., Sherwood, S. C., Peterson, T. C., Haimberger, L., Parker, D. E., Tett, S. F. B., Santer, B. D., Fereday, D. R., and Kennedy, J. J.: A quantification of uncertainties in historical tropical tropospheric temperature trends from radiosondes, J. Geophys. Res.-Atmos., 116, D12116, doi:10.1029/2010jd015487, 2011.

Turner, D. D., Clough, S. A., Liljegren, J. C., Clothiaux, E. E., Cady-Pereira, K., and Gaustad, K. L.: Retrieving liquid water path and precipitable water vapor from Atmospheric Radiation Measurement (ARM) microwave radiometers, IEEE T. Geosci. Remote, 45, 3680-3690, doi:10.1109/TGRS.2007.903703, 2007.

Vaisala: Vaisala Radiosonde RS41 Measurement Performance White Paper. Ref. B211356EN-A (C) Vaisala, 2013.

Vaisala: Comparison of Vaisala Radiosondes RS41 and RS92 White Paper. Ref. B211317EN - B (C) Vaisala, Helsinki, Finland, 2014.

Vaisala: Vaisala Radiosonde RS41 White Paper - Ground Check Device R141. Ref. B211539EN-A (C) Vaisala, 2015.

Vömel, H., Selkirk, H., Miloshevich, L., Valverde-Canossa, J., Valdés, J., Kyrö, E., Kivi, R., Stolz,W., Peng, G., and Diaz, J. A.: Radiation Dry Bias of the Vaisala RS92 Humidity Sensor, J. Atmos. Ocean. Tech., 24, 953-963, 2007.
Wang, J., Carlson, D. J., Parsons, D. B., Hock, T. F., Lauritsen, D., Cole, H. L., Beierle, K., and Chamberlain, E.: Performance of operational radiosonde humidity sensors in direct comparison with a chilled mirror dew-point hygrometer and its climate implication, Geophys. Res. Lett., 30, 1860, doi:10.1029/2003GL016985, 2003.

Wang, J., Zhang, L., Dai, A., Immler, F., Sommer, M., and Vomel, H.: Radiation dry bias correction of Vaisala RS92 humidity data and its impacts on historical radiosonde data, J. Atmos. Oceanic Technol., 30, 197-214, doi:10.1175/JTECH-D-1200113.1, 2013

Xie, S., Zhang, M., Branson, M., Cederwall, R. T., Del Genio, A. D., Eitzen, Z. A., Ghan, S. J., Iacobellis, S. F., Johnson, K. L., Khairoutdinov, M., Klein, S. A., Krueger, S. K., Lin, W., Lohmann, U., Miller, M. A., Randall, D. A., Somerville, R. C. J., Sud, Y. C., Walker, G. K., Wolf, A., Wu, X., Xu, K.-M., Yio, J. J., Zhang, G., and Zhang, J.: Simulations of midlatitude frontal clouds by SCMs and CSRMs during the ARM March 2000 Cloud IOP, J. Geophys. Res., 110, D15S03, doi:10.1029/2004JD005119, 2005.

Xie, S., Hume, T., Jakob, C., Klein, S., McCoy, R., and Zhang, M.: Observed large-scale structures and diabatic heating and drying profiles during TWP-ICE, J. Climate, 23, 57-79, doi:10.1175/2009JCLI3071.1, 2010.

Xie, S., Zhang, Y., Giangrande, S. E., Jensen, M. P., McCoy, R., and Zhang, M.: Interactions between cumulus convection and its environment as revealed by the MC3E sounding array, J. Geophys. Res., 119, 11784-11808, doi:10.1002/2014JD022011, 2015.

Xu, K.-M., Cederwall, R. T., and Xie, S.: An intercomparison of cloud-resolving models with the ARM summer 1997 IOP data, Q. J. Roy. Meteor. Soc., 128, 593-624, 2002.

Yu, H., Ciesielski, P., Wang, J., Kuo, H.-C., Vomel, H., and Dirksen, R.: Evaluation of humidity correction methods for Vaisala RS92 tropical sounding data, J. Atmos. Ocean. Tech., 32, 397 411, doi:10.1175/JTECH-D-14-00166.1, 2014.

Zhang, M. H. and Lin, J. L.: Constrained variational analysis of sounding data based on column-integrated budgets of mass, heat, moisture and momentum: approach and application to ARM measurements, J. Atmos. Sci., 54, 1503-1524, 1997.

Zhang, M. H., Lin, J. L., Cederwall, R. T., Yiou, J. J., and Xie, S. C.: Objective analysis of ARM IOP data: method and sensitivity, Mon. Weather Rev., 129, 295-311, 2001.

Zhao, C., Xie, S., Klein, S. A., McCoy, R., Comstock, J., Deng, M., Dunn, M., Hogan, R., Huang, D., Jensen, M. P., Mace, G. G., McFarlane, S., O'Connor, E., Protat, A., Shupe, M., Turner, D. D., and Wang, Z.: Understanding differences in current ARM ground-based cloud retrievals, J. Geophys. Res., 117, D10206, doi:10.1029/2011JD016792, 2012.

Zhao, T., Dai, A., and Wang, J.: Trends in tropospheric humidity from 1970 to 2008 over China from a homogenized radiosonde dataset,J. Climate, 25, 4549-4567, doi:10.1175/JCLID-11-00557.1, 2012. 